"This is the peer reviewed version of the following article: Klikar, M., Solanke, P., Tydlitát, J. and Bureš, F. (2016), Alphabet-Inspired Design of (Hetero)Aromatic Push-Pull Chromophores. The Chemical Record, 16: 1886-1905. doi:10.1002/tcr.201600032, which has been published in final form at https://dx.doi.org/10.1002/tcr.201600032. This article may be used for non-commercial purposes in accordance With Wiley-VCH Terms and Conditions for self-archiving".

This postprint version is available from http://hdl.handle.net/10195/66348 


\title{
Alphabet-Inspired Design of (Hetero)Aromatic Push-Pull Chromophores
}

\author{
Milan Klikar, ${ }^{[a]}$ Parmeshwar Solanke, ${ }^{[a]}$ Jiř́i Tydlitát, ${ }^{[a]}$ and Filip Bureš*[a]
}

\begin{abstract}
Push-pull molecules represent a unique and fascinating class of organic $\pi$-conjugated materials. Herein, we provide a summary of their recent extraordinary design inspired by letters of the alphabet, especially focusing on $\mathrm{H}_{-}, \mathrm{L}_{-}, \mathrm{T}_{-}, \mathrm{V}_{-}, \mathrm{X}-$, and Y-shaped molecules. Representative structures from each class were presented and their fundamental properties and prospective applications were discussed. In particular, emphasis is given to molecules recently prepared in our laboratory with T-, X-, and Y-shaped arrangements based on indan-1,3-dione, benzene, pyridine, pyrazine, imidazole, and triphenylamine. These push-pull molecules turned out to be very efficient charge-transfer chromophores with tunable properties suitable for second-order nonlinear optics, two-photon absorption, reversible $\mathrm{pH}$-induced and photochromic switching, photocatalysis, and intercalation.
\end{abstract}

Keywords: chromophores, conjugation, donor-acceptor systems, photochemistry, structure-activity relationships

\section{Introduction}

Organic push-pull molecules represent a subclass of $\pi$-conjugated systems that are end-capped with electron donor(s) and electron acceptor(s). The D- $\pi$-A arrangement allows direct interaction of the donor (D) and the acceptor (A) through the $\pi$-system, so-called intramolecular charge transfer (ICT), and generates a new molecular orbital. The excitation of the electrons within the new orbital can be achieved by visible light, which gives push-pull molecules their color (charge-transfer (CT) chromophores). Apart from distinct optical properties, the ICT significantly polarizes the whole $\pi$-system and D- $\pi$-A molecules possess a dipolar character. The ICT can graphically be expressed by limiting resonance forms (Figure 1). ${ }^{[1]}$

The main advantage of CT chromophores with the D- $\pi$ A arrangement over other inorganic and organic dyes can be seen in their well-defined and tunable structures and predictable properties. In principal, the fundamental features of push-pull molecules, such as the HOMO and LUMO levels and their difference (band gap), position of the longestwavelength absorption maxima (CT band), and dipole moment, can be modulated by alternating the A, D, and $\pi$ parts. Variation of the electron-withdrawing and -releasing behavior of $\mathrm{A}$ and $\mathrm{D}$, modification of the $\pi$-system (length, composition, and polarizability), and overall chromophore arrangement (number and mutual arrangement of the $\mathrm{A}$ and $\mathrm{D}$ moieties, planarity, and further auxiliary functionalization) currently represent well-developed tools for tailoring D- $\pi-A$

\footnotetext{
${ }^{[a]}$ M. Klikar, P. Solanke, J. Tydlitát, F. Bureš

Institute of Organic Chemistry and Technology,

Faculty of Chemical Technology

University of Pardubice

Studentská 573

Pardubice 53210 (Czech Republic)

E-mail: filip.bures@upce.cz
}

systems towards desired applications. ${ }^{[1,2]}$ In this respect, the incorporation of a heteroatom into the $\pi$-conjugated backbone seems to be a newer, but also powerful strategy directed towards the modulation of optoelectronic properties. Six- and five-membered heterocycles, such as azines, ${ }^{[3]}$ thiophenes, ${ }^{[4,5]}$ and imidazoles, ${ }^{[6]}$ belong to the most widely employed heterocycles. Heteroaromatic compounds represent an alternative to hydrocarbon scaffolds, while the heteroatoms bring higher polarizability, as well as thermal and chemical robustness, and behave as auxiliary electron donors/acceptors, and constitute a place of further modification (acid/base and coordination properties).

From a historical point of view, the first push-pull organic molecules were used as dyestuffs, for example, the synthetic dye mauveine. ${ }^{[7]}$ After invention of the laser in 1960 , D- $\pi-A$ systems also became important media for nonlinear optics (NLOs). ${ }^{[8]}$ More recently, organic push-pull molecules have notably infiltrated materials chemistry, and organic electronics and optoelectronics currently represent well-developed and burgeoning areas. ${ }^{[9]}$ The concept of $\pi$-conjugated molecules with the D- $\pi$-A arrangement has been advantageously utilized in dye-sensitized solar cells (DSSCs), ${ }^{[10]}$ bulk-heterojunction solar cells (BHJSCs), ${ }^{[11]}$ organic light-emitting diodes (OLEDs), ${ }^{[12]}$ two-photon absorbers (2PAs), ${ }^{[13]}$ and near-infrared absorbing dyes. $^{[14]}$

In addition to the ordinary linear D- $\pi$-A systems, CT chromophores may also adopt advanced quadrupolar (D- $(\pi$ $\mathrm{A})_{2}$ or $\left.\mathrm{A}-(\pi-\mathrm{D})_{2}\right)$ and tripodal $\left(\mathrm{D}-(\pi-\mathrm{A})_{3}\right.$ or $\left.\mathrm{A}-(\pi-\mathrm{D})_{3}\right)$ arrangements. In recent years, extraordinary arrangements of push-pull chromophores inspired by letters of the alphabet appeared in the literature. Hence, based on these, as well as our contributions, we cover herein the design, properties, and further use of selected classes of such peculiar chromophores. In alphabetical order, these include $\mathrm{H}_{-}, \mathrm{L}-, \mathrm{T}-, \mathrm{V}-, \mathrm{X}-$, and Yshaped molecules, as schematically shown in Figure 2. Most frequently, the letter shape corresponds to either $\pi$-conjugated 


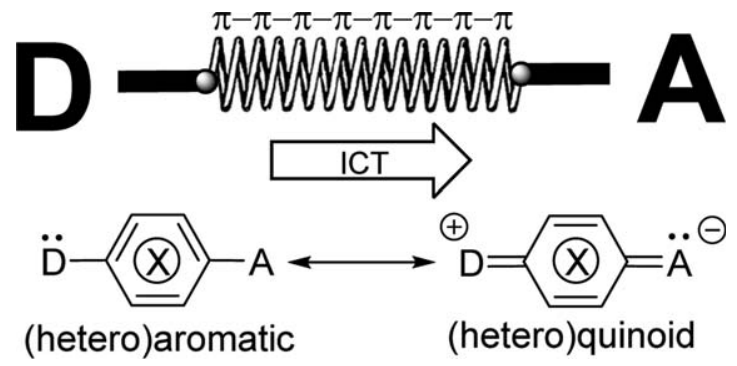

Fig. 1. Schematic representation of a D- $\pi-A$ system and two limiting resonance forms of a (hetero)aromatic push-pull molecule ( $\mathrm{X}=$ any heteroatom incorporated within the $\pi$-scaffold).

or non-conjugated chromophore backbones, whereas the electron acceptors and donors are attached to the periphery.

\section{H-Shaped Molecules}

Undoubtedly, H-shaped molecules represent one of the most extraordinary arrangements of push-pull molecules known to date. Three general classes of $\mathrm{H}$ chromophores with different $\mathrm{A}$ and $\mathrm{D}$ arrangements along the $\mathrm{H}$-shaped backbone can be found in the current literature: 1) two parallel D- $\pi$-A units connected by a (non)conjugated spacer, 2) two bridged upside-down D- $\pi$-A systems, and 3) $\mathrm{H}$-shaped core bearing a central electron-withdrawing moiety and four peripheral donors.

The first class of $\mathrm{H}$-shaped chromophores was extensively investigated by Zhang et al. (Figure 3). ${ }^{[15]}$ 9,10-Dihydroanthracene has been utilized as a central $\pi$-conjugated core with hydroxy/alkoxy electron donors appended at positions C4/C5 and acceptors linked through azo spacers at $\mathrm{C} 1 / \mathrm{C} 8$. Target push-pull molecules $\mathbf{1}$ and $\mathbf{2}$ were synthesized in a two-step reaction sequence through a key intermediate, 1,8-dihydroxy-9,10-dihydroantracene, which was prepared from 1,8dihydroxy-9,10-anthraquinone, followed by azo-coupling. Compared with analogous linear push-pull chromophore 1a, two parallel D- $\pi$-A units, as in $\mathbf{1}$, showed a remarkably enhanced second-order NLO response, which was not accompanied by a large redshift of the longest-wavelength absorption maxima (nonlinearity-transparency trade-off; Table 1). Chromophore $\mathbf{2}$ embedded into a fluoro-containing aromatic main-chain PI afforded NLO-active organic material $\mathbf{3}$ with a high macroscopic nonlinearity, $d_{33}$, exceeding $70 \mathrm{pm} / \mathrm{V}$, optical transparency above $400 \mathrm{~nm}$ and good thermal stability $\left(T_{\mathrm{g}}=198^{\circ} \mathrm{C}, T_{\mathrm{d}}=245^{\circ} \mathrm{C}\right)$. Lu et al. further used the 9,10 -
Milan Klikar was born in Turnov, Czech Republic (1988), and studied organic chemistry at the University of Pardubice (2007-2013), and is currently pursuing doctoral studies under the guidance of $\mathrm{F}$. Bureš. In 2014, he joined the Institute of Organic Chemistry as a Scientific Re-

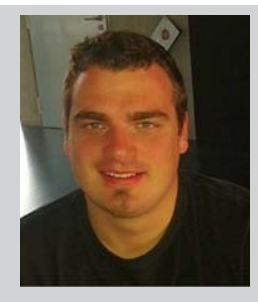
searcher. His main research interests involve the synthesis and characterization of novel NLO-active materials, especially focusing on malonic acid derivatives, as well as the thermal behavior of organic $\pi$-systems.

Parmeshwar Solanke was born in India, in 1982. He received his Master's degree in organic chemistry from The Swami Ramanand Teerth Marathwada University Nanded (India). He received his $\mathrm{PhD}$ in 2015 from the University of Pardubice under the supervision of $F$. Bureš. Before

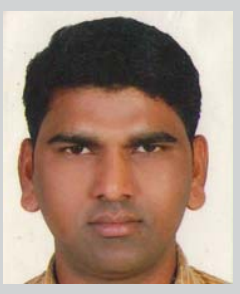
starting his doctoral studies, he worked as a Research Assistant at the National Chemical Laboratory, Pune (India). His research interests include the synthesis, properties, and applications of novel materials for nonlinear optics, organic solar cells (DSSCs), and organic light-emitting diodes (OLEDs).
Jiří Tydlitát was born in Pardubice, Czech Republic (1982), and studied chemistry at the University of Pardubice (20022008). He received his $\mathrm{PhD}$ in organic chemistry (2008-2014) from the University of Pardubice. He worked as a (post)doctoral fellow in the groups of G.

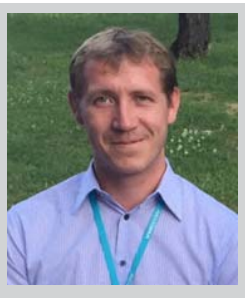
Mlostoń (University of Łódź, Poland, 2011) and P. Sadler (University of Warwick, UK, 2015). He currently works as an Assistant Professor at the Institute of Organic Chemistry. His research is focused on polycyclic (hetero)aromatics as basic building blocks for novel fluorophores and NLO materials.

Filip Bureš was born in Poprad, Slovakia (1979), and studied chemistry at the University of Pardubice (1997-2002). He received his $\mathrm{PhD}$ in organic chemistry (2003-2005) from the University of Pardubice, where he was also habilitated in 2010. He pursued (post)doctoral studies

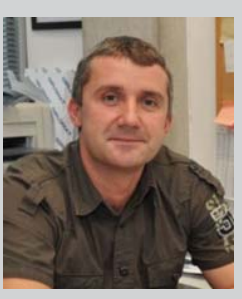
with Prof. P. Knochel (LMU, Munich) and Prof. F. Diederich (ETH, Zurich). He currently leads his own working group at the Institute of Organic Chemistry, University of Pardubice, which focuses on the design and synthesis of $\pi$-conjugated molecules for miscellaneous optoelectronic applications. 


\section{HLTVXY \\ $A=$ electron acceptor,$D=$ electron donor}

Fig. 2. Alphabet-inspired design of push-pull molecules.

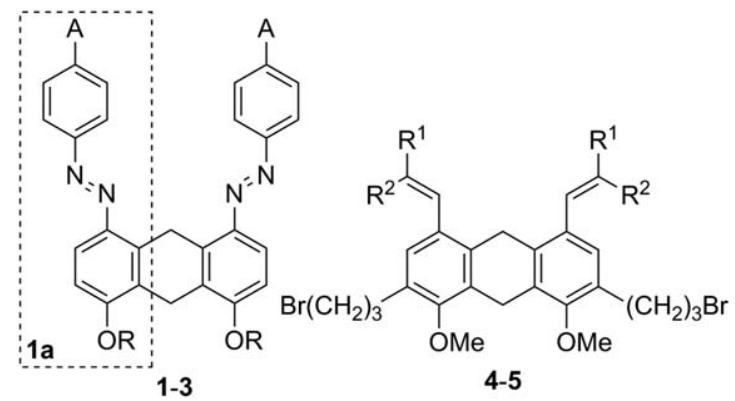

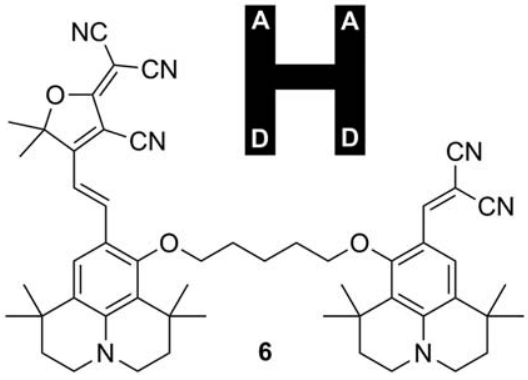

Fig. 3. H-shaped push-pull molecules with two parallel D- $\pi$-A units.

Table 1. Fundamental properties of chromophores 1-5.

\begin{tabular}{lllcc}
\hline & & \multicolumn{3}{c}{$\lambda_{\text {max }}$} \\
{$[\mathrm{nm}]^{[\mathrm{a}]}$} & $\mathrm{NLO}$ properties \\
\hline $\mathbf{1 a}$ & $\mathrm{R} / \mathrm{R}^{1}$ & $\mathrm{~A} / \mathrm{R}^{2}$ & 388 & $70 / 28^{[\mathrm{b}]}$ \\
$\mathbf{1}$ & $\mathrm{H}$ & $\mathrm{NO}_{2}$ & 398 & $277 / 105^{[\mathrm{b}]}$ \\
$\mathbf{2}$ & $\mathrm{N}$ & $\mathrm{CF}_{2}$ & 367 & $252 / 117^{[\mathrm{b}]}$ \\
$\mathbf{3}$ & $\mathrm{PI}$ & $\mathrm{CF}_{3}$ & $353^{[\mathrm{c}]}$ & $70.2^{[\mathrm{d}]}$ \\
$\mathbf{4}$ & $\mathrm{H}$ & $\mathrm{NO}_{2}$ & 332 & $4151^{[\mathrm{e}]}$ \\
$\mathbf{5}$ & $\mathrm{CN}$ & $\mathrm{CN}^{[\mathrm{N}}$ & 332 & $1538^{\mathrm{e}]}$ \\
\hline
\end{tabular}

[a] Measured in THF. [b] First hyperpolarizability $(\beta) /$ static first hyperpolarizability $\left(\beta_{0}\right)$ measured in THF by hyper-Rayleigh scattering at $1064 \mathrm{~nm}$ versus $p$-nitroaniline (in $10^{-30} \mathrm{esu}$ ). [c] Measured in poled thin polyimide (PI) films. [d] Macroscopic second-harmonic coefficient, $d_{33}$ (in $\mathrm{pm} / \mathrm{V}$ ). [e] $\mu \beta$ product determined by solvatochromic method versus $p$-nitroaniline (in $10^{-48} \mathrm{esu}$ ).

dihydroanthracene parent scaffold for the construction of chromophores $\mathbf{4}$ and $\mathbf{5}$, bearing methoxy donors and nitro and dicyanovinyl (DCV) acceptors (Figure 3 and Table 1). ${ }^{[16]}$ In a very similar way as that discussed above, they demonstrated that $\mathrm{H}$-shaped chromophores possessed significantly improved optical nonlinearities over mono D- $\pi$-A systems. Interesting H-shaped chromophore 6 was prepared by Zhen et al. ${ }^{[17]}$ This

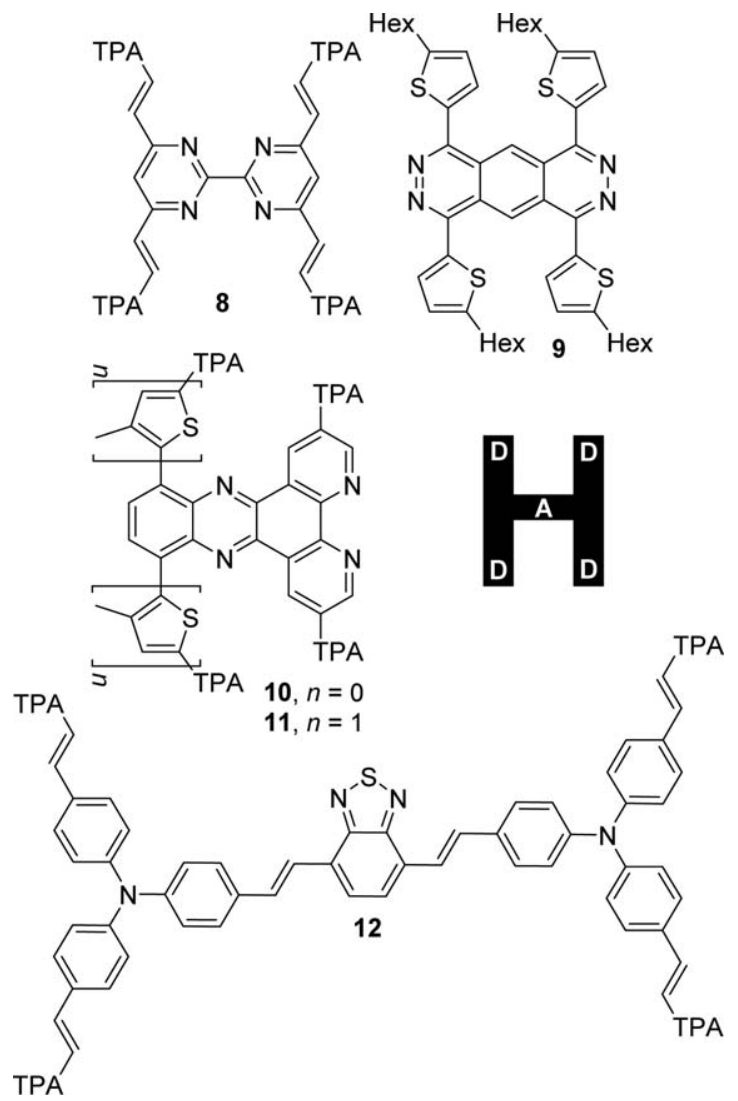

Fig. 4. H-shaped push-pull molecules 8-12 with a central acceptor and peripheral donors (TPA $=4$-diphenylanilino).

molecule contains two julolidine donors saturating two different electron acceptors (tricyanofuran (TCF) and DCV) across two different $\pi$-linkers. NLO measurements of unsymmetrical 6 embedded into polycarbonate showed improved poling efficiency, which was due to a reduced intermolecular dipoledipole interaction (also supported by DFT calculations).

The concept of two D- $\pi-\mathrm{A}$ azobenzenes cross-linked through a spacer into $\mathrm{H}$-shaped molecules has recently also been utilized in polymer chemistry. ${ }^{[18]}$ In this respect, various dendron-like, oligomeric, (hetero)aromatic, and aliphatic spacers and polymeric backbones were introduced by $\mathrm{Li}$ et al. It has been shown that such $\mathrm{H}$-shaped chromophore embedding leads to polymeric materials with an enhanced NLO effect, optical transparency, and chemical and thermal robustness.

In contrast to previous $\mathrm{H}$-shaped chromophores, the antiparallel arrangement of two linked D- $\pi$-A units is much scarcer, most likely due to tedious synthesis. In 2014, Dong et al. reported on push-pull tetraarylbuta-1,3-diene 7 (Figure 4), with aggregation-enhanced emission and mechanotronic fluorescence properties. ${ }^{[19]}$ Among others, the D- $\pi-\mathrm{A}$ $\mathrm{H}$-shaped arrangement turned out to be the most beneficial 


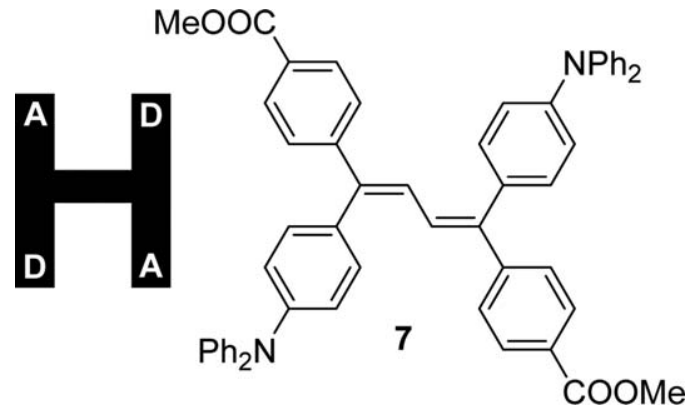

Fig. 5. H-shaped push-pull molecule 7 with two antiparallel D- $\pi$-A units.

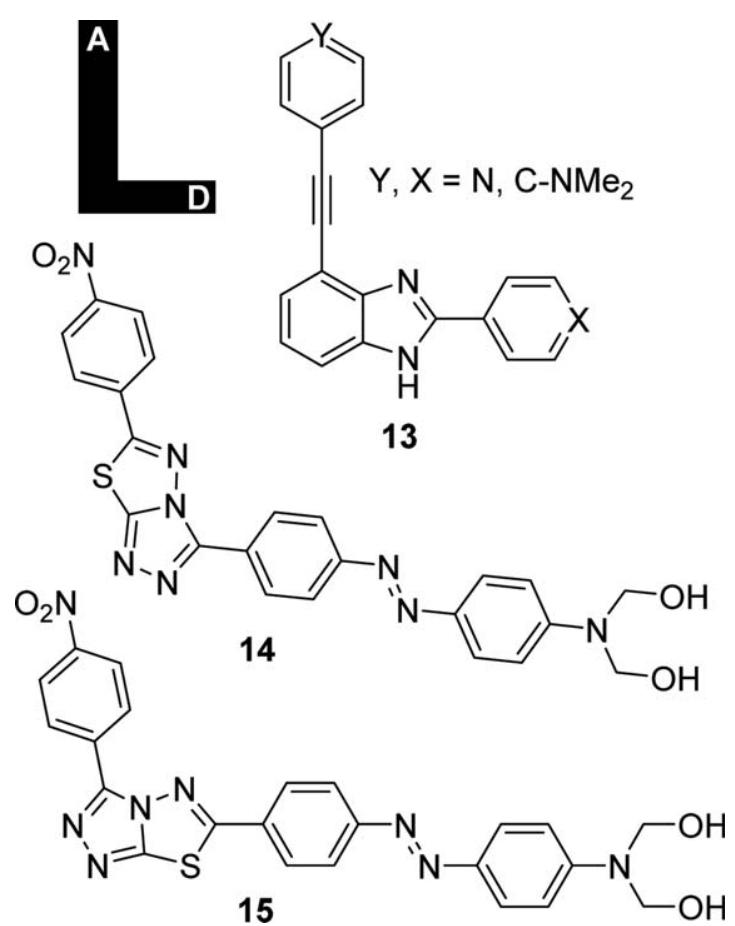

Fig. 6. L-shaped push-pull molecules $\mathbf{1 3 - 1 5}$ with benzo[d]imidazole and $s$-triazolo[3,4-b] thiadiazole cores.

by providing the molecule with a large dipole moment, mechanochromic contrast, and high solid-state fluorescence quantum yield.

The third group of $\mathrm{H}$-shaped molecules with a central acceptor unit end-capped with four peripheral electron donors is shown in Figure 5. In these molecules, the central $\pi$-conjugated scaffold is often based on heterocyclic moieties, such as bipyrimidine $(\mathbf{8}),{ }^{[20]}$ 2,3,6,7-tetraazaanthracene (9), ${ }^{[21]}$ dipyrido[3,2-a:2 $\left.2^{\prime}, 3^{\prime}-c\right]$ phenazine $(\mathbf{1 0}$ and $\mathbf{1 1}),{ }^{[22]}$ and 2,1,3-benzothiadiazole (12). ${ }^{[23]}$ Bipyrimidine $\mathbf{8}$ has been investigated as a $D_{2 \mathrm{~d}}$ octupolar chromophore with a large second-order nonlinear optical response $\left(\beta / \beta_{0}=190 / 130 \times\right.$ $10^{-30} \mathrm{esu}$, measured by harmonic light scattering at $1640 \mathrm{~nm}$ in $\mathrm{CHCl}_{3}$ ), tetraazaanthracene 9 showed typical n-type characteristics and could be considered as a promising candidate for organic electronic devices. In phenazines 10 and 11, the ICT can easily be tuned by extending the $\pi$-system with thienylene units $(n=0$ or 1$)$. These chromophores showed outstanding thermal stability $\left(T_{\mathrm{d} 10}\right.$ over $\left.500^{\circ} \mathrm{C}\right)$ and were suggested as organic materials suitable for OLEDs, DSSCs, and organic field-effect transistors (OFETs). Branched benzothiadiazole derivative 12 emitted red light, with $\lambda_{\max }^{\mathrm{E}}=621 \mathrm{~nm}$, with a fluorescence quantum yield of $33 \%$ and showed a two-photon absorption cross-section, $\delta_{2 \mathrm{PA}}$, of $351 \mathrm{GM}(820 \mathrm{~nm})$.

\section{L-Shaped Molecules}

Selected heterocyclic moieties can also be employed as central $\pi$-backbones for the construction of L-shaped push-pull molecules. Figure 6 shows two examples based on benzo $[d]$ imidazoles $(\mathbf{1 3})^{[24]}$ and $s$-triazolo[3,4-b] thiadiazoles (14 and 15)..$^{[25]}$ "Half-cruciforms" 13 could easily be synthesized in a two-step reaction sequence and were used as fluorophores that significantly responded to/sensed various bases, acids, and anions, depending on the orientation of the $N, N$-dimethylamino donor and pyridine acceptor.

In 2009, Centore et al. introduced triazolothiazole as a new central heteroaromatic scaffold for the construction of NLOphores $14\left(\lambda_{\max }=469 \mathrm{~nm}(\mathrm{DMF}) ; \mu \beta=430 \times 10^{-48}\right.$ esu (EFISH, $1900 \mathrm{~nm}, \mathrm{DMF})$ ) and $15\left(\lambda_{\max }=489 \mathrm{~nm}\right.$ (DMF); $\mu \beta=980 \times 10^{-48}$ esu $($ EFISH, $\left.1900 \mathrm{~nm}, \mathrm{DMF})\right) .{ }^{[25]}$ As can be seen, a proper orientation of the donor/acceptor around the parent heterocyclic core redshifts the longestwavelength absorption maxima by $20 \mathrm{~nm}$ and more than doubles the NLO response.

\section{T-Shaped Molecules}

T-shaped chromophores represent another extraordinary structural arrangement of push-pull molecules. Several (hetero)aromatic $\pi$-backbones were utilized to construct such molecules. In 2013, we showed the first systematic modification of an indan-1,3-dione-fused benzene ring through cross-coupling reactions, leading to T-shaped chromophores $1 \mathbf{1 6}^{[26]}$ The straightforward synthetic pathway starts from inexpensive phthalic anhydride and its gradual iodination, Claisen condensation with ethyl-acetoacetate, and decarboxylation afforded 4,7-diiodoindan-1,3-dione as an intermediate capable of further Knoevenagel condensation and cross-coupling reaction (Scheme 1). In this modular way, various lower and peripheral electron donors can be attached to the central indan-1,3-dione acceptor to generate 16 tripodal $(\mathrm{D}-\pi)_{2}-\mathrm{A}-\pi-\mathrm{D}$ molecules with systematically modified electron donors (D) and the $\pi$-system length $(n)$. These structural modifications allowed tuning of 


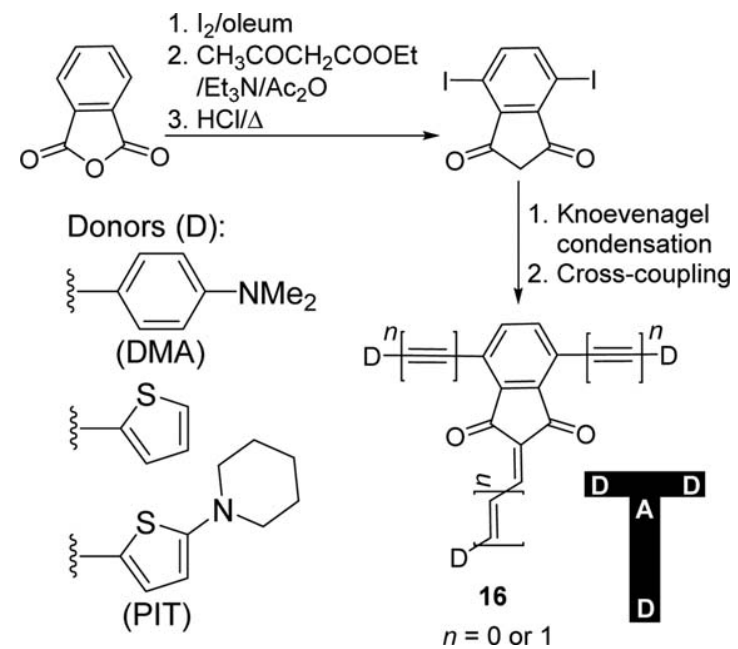

Scheme 1. Structure and synthesis of T-shaped chromophores $\mathbf{1 6}$ based on an indan-1,3-dione central acceptor moiety.

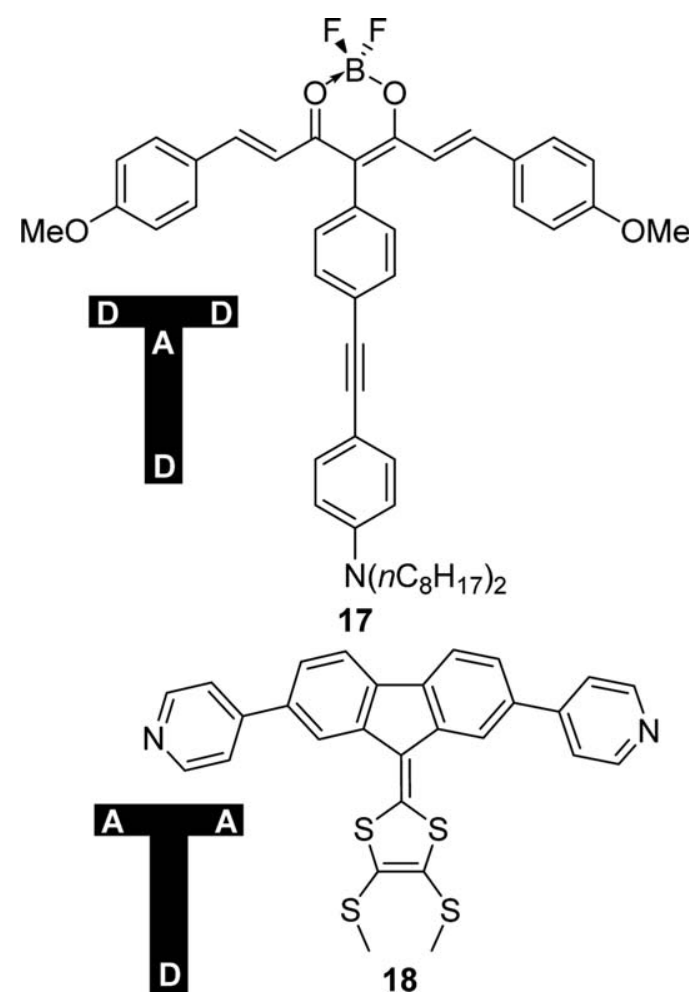

Fig. 7. Tripodal T-shaped chromophores 17 and 18 with $(D-\pi)_{2}-A-\pi-D$ and $(\mathrm{A}-\pi)_{2}$ - $\mathrm{D}$ arrangements.

the electrochemical/optical gaps within the range of 2.13$1.43 / 2.55-1.93 \mathrm{eV}$ and provided optical nonlinearities with $\mu \beta=230-2100 \times 10^{-48}$ esu $\left(\right.$ EFISH, $\left.1907 \mathrm{~nm}, \mathrm{CH}_{2} \mathrm{Cl}_{2}\right){ }^{[27]}$ It turned out that the lower electron donor was involved in more-efficient ICT than the peripheral ones.
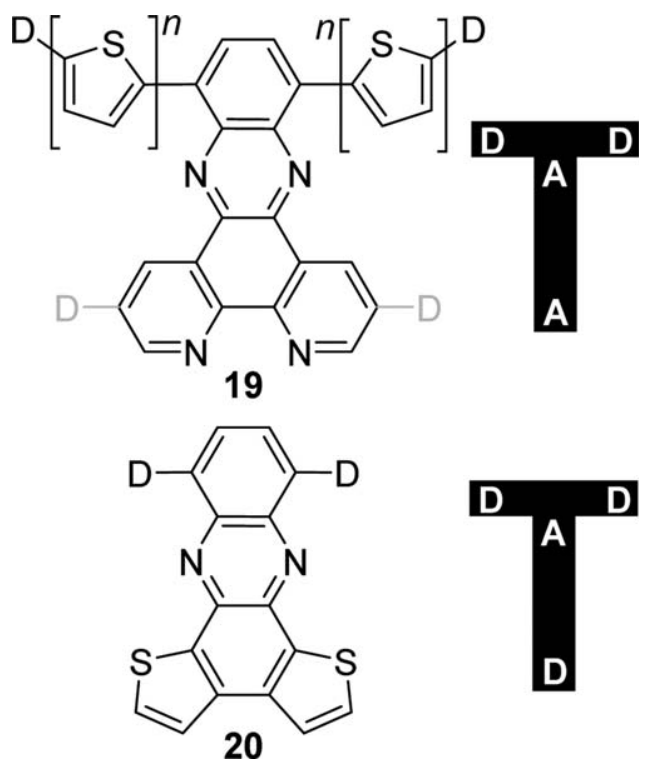

Fig. 8. Phenazine-derived CT chromophores 19 and 20.

Fages et al. utilized 1,3-dicarbonyl compounds as part of the electron-withdrawing dioxaborine moiety in $\mathbf{1 7}$ (Figure 7) saturated by three peripheral methoxy and dialkylamino donors. ${ }^{[28]}$ Spectral investigations of this molecule revealed photoinduced ICT from the peripheral branches, resulting in two closely lying excited states with the possibility of controlling the ICT through solvent, protonation, and complexation. $9 H$-Fluorene can also be used as a parent hydrocarbon scaffold for the construction of CT chromophore 18 (Figure 7) equipped with two accepting pyridin-4-yl moieties and a 1,3dithiole donor. ${ }^{[29]}$ The extent of ICT was investigated by X-ray analysis, electrochemistry, electronic absorption spectra, and was completed by DFT calculations.

Heteroaromatic phenazine is probably the most often employed $\pi$-backbone for the construction of T-shaped molecules bearing a central acceptor moiety. Figure 8 shows two representative derivatives, $\mathbf{1 9}$ and $\mathbf{2 0}$, with a lower bipyridine acceptor or bithiophene donor and two peripheral donors D (TPA, carbazole, and 4-methoxyphenyl). Positioning of the D along the $\pi$-conjugated core of $\mathbf{1 9}$ significantly affected the absorption and emissive properties, as well as thermal stability. Moreover, due to a $\mathrm{N}=\mathrm{C}-\mathrm{C}=\mathrm{N}$ (bipy) binding pocket in 19, these chromophores can also be used as auxiliaries to chelate $\mathrm{Ru}(\mathrm{II}) .{ }^{[30]}$ The latter type of chromophores $\mathbf{2 0}$ showed structured absorption covering almost the whole range of visible light, provided red emission, and could grow into straight microwires in DCM/ethanol. ${ }^{[31]}$ In particular, chromophore 20 equipped with TPA donors showed a high fluorescence quantum yield, large Stokes' shift, and low optical loss coefficient of $0.29 \mathrm{~dB} / \mu \mathrm{m}$, and therefore, could be considered as a promising red-emitting waveguide material. In general, 


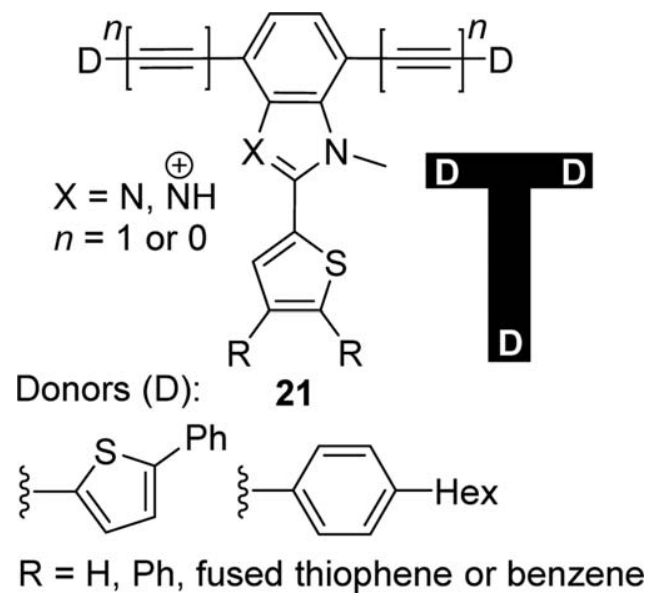

Fig. 9. T-shaped molecules 21 built on the benzo[d] imidazole core.

phenazine-derived T-shaped molecules proved to be chromophores well suited for tuning and controlling the $\mathrm{ICT},{ }^{[32]}$ particularly when going to more extended bisphenazines. ${ }^{[33]}$ For instance, T-shaped bisphenazines were thoroughly investigated by Lee et al. as self-assembling molecules or organogelators. ${ }^{[34]}$

Apart from six-membered diazines, benzo[d]imidazole can also be employed as a central heteroaromatic scaffold for the construction of either L-shaped half-cruciforms 13 (Figure 6) or T-shaped chromophores. For instance, Nakashima et al. published a series of papers focusing on 2,4,7-trisubstitued benzo[d] imidazole tripodal derivatives 21 (Figure 9). ${ }^{[35]}$ In these molecules, the central benzo $[d]$ imidazole was primarily used as an acid-responsive core, which upon protonation only redshifted the emission maxima without significantly affecting the position of the absorption CT band. In contrast to analogous linear chromophores, T-shaped $\mathbf{2 1}$ showed twisted intramolecular charge transfer (TICT), and therefore, orthogonally allocated branches at positions $\mathrm{C} 4$ and $\mathrm{C} 7$ seemed to be essential for the emergence of TICT. A vertical $\pi$-system with higher quinoid character generally suppressed the TICT emission, leading to a more planar ICT state. Benzimidazolium T-shaped molecules were also utilized as a new templating motif for the formation of [2]pseudorotaxanes, in which the T-shape arrangement greatly enhanced the association with crown ethers when compared with simple linear analogues. ${ }^{[36]}$

Some other spiro- and carbazole-derived T-shaped pushpull molecules appeared in the literature, with applications ranging from photoinduced switches to amphiphilic molecules. ${ }^{[37,38]}$

\section{V-Shaped Molecules}

$\mathrm{V}$-shaped push-pull molecules (also referred to as U- or $\Lambda$-shaped) appear in the current literature much more often

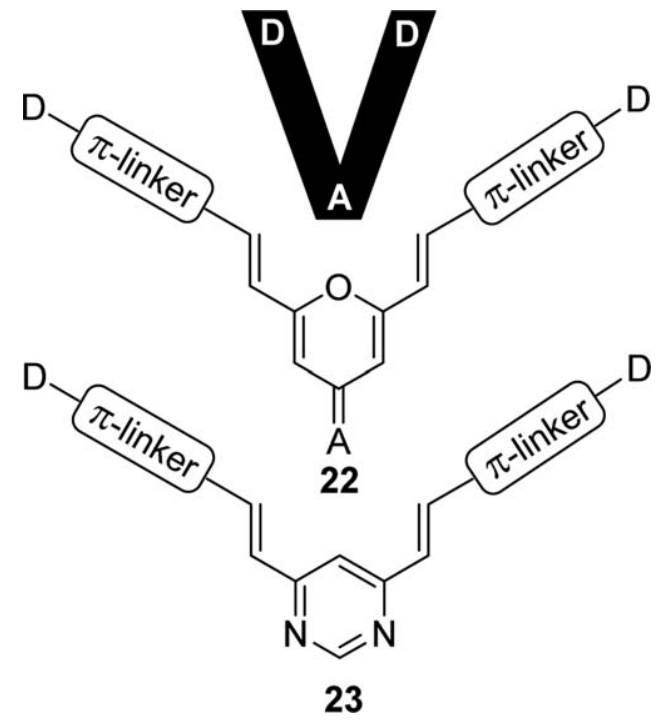

Fig. 10. Pyran- and diazine-derived V-shaped push-pull molecules.

than the previous three series. Hence, in the following section, the most common structural motives used for their construction, such as pyran, pyridine, diazines, (di)azinium salts, carbazole, and others, are summarized. Pyran belongs to one of the most widely employed heteroaromatic compounds used as either proaromatic electron donor or $\pi$-conjugated central moieties (Figure 10; 22). ${ }^{[39]}$ Whereas electron donors in 22 are mostly connected at the positions $\mathrm{C} 2$ and C6, electronwithdrawing moieties are introduced at the position $\mathrm{C} 4$ through a Knoevenagel reaction. The electron-releasing moieties (D) comprise $N, N$-dialkyl(aryl)amines, indole, carbazole, and proaromatic $4 H$-pyran-4-ylidene; the A part is represented by the strongest electron-withdrawing moieties, such as DCV, (thio)barbituric acid, isoxazolone, and TCF. The $\pi$-system is often extended through polarizable 2,5-thienylene linkers. ${ }^{[40]}$ It turned out that the central pyranylidene moiety behaved strictly as a polyenic spacer, not as an auxiliary donor, unlike the pyranylidene terminal donor. Moreover, both C2/C6 branches can be unsymmetrically substituted, which further improves the second-order NLO response and such quadrupolar molecules possess absorption maxima reaching $700 \mathrm{~nm}$ with large intrinsic hyperpolarizabilities, $\beta / \mu \beta$, up to $490 /$ $7160 \times 10^{-30 / 48}$ esu (HRS or EFISH experiments). Perspective applications of such powerful CT chromophores range from solvent probes to optic modulators, frequency doublers, and electro-optic polymers.

A very similar structural pattern to $\mathbf{2 2}$ can also be built on 2,6-disubstituted pyridine. ${ }^{[41]}$ Moreover, the presence of a basic pyridine nitrogen atom predestines such molecules to be used as $\mathrm{pH}$-sensitive chromophores; the absorption maxima of which undergo significant redshift upon protonation (the ICT enhancement via pyridine to pyridinium acceptor 


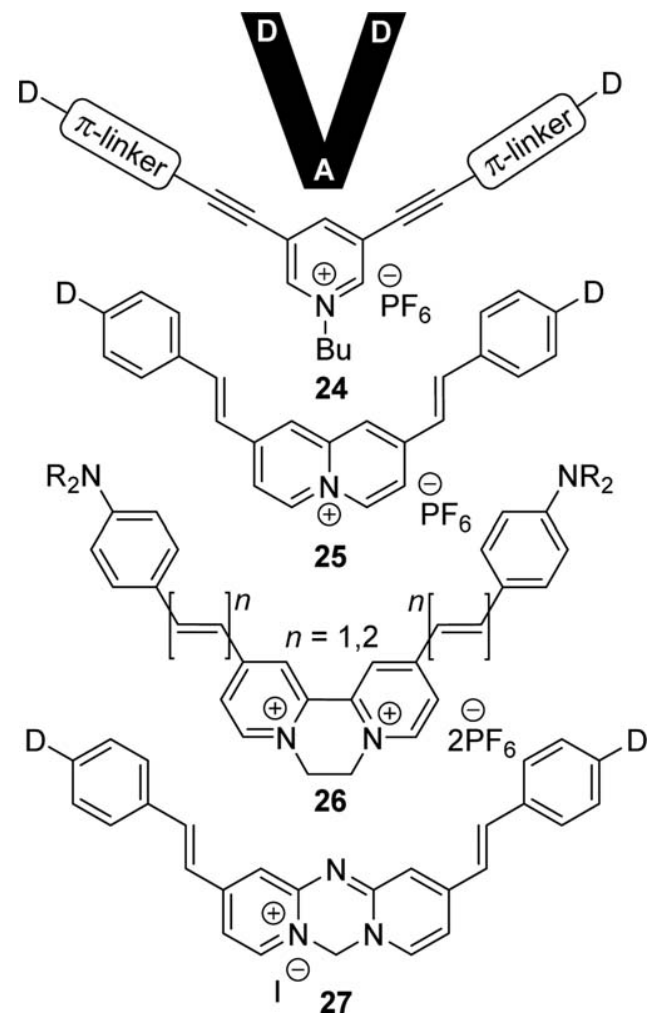

Fig. 11. Cationic V-shaped chromophores based on various azinium ions.

replacement). The concept of using a central (di)azine acceptor moiety for V-shaped push-pull molecules has recently been extended and reviewed by Achelle et al. ${ }^{[3 a, b]}$ For instance, 4,6bis(arylvinyl)pyrimidines $\mathbf{2 3}$ proved to be promising CT chromophores with facile synthesis and tunable optical properties. ${ }^{[42]}$ By a proper selection of the peripheral donor groups and solvents, the absorption and emission maxima can be shifted over $200 \mathrm{~nm}$. Various applications of such derivatives were demonstrated, ranging from second-order NLOs, colorimetric and luminescent $\mathrm{pH}$ sensors, ion sensing, and halochromic materials. In particular, 4-( $N, N$-diphenylamino)phenyl- and 6-methoxynaphthalen-2-yl-substituted derivatives proved to be efficient 2PAs with a very high $\delta_{2 \mathrm{PA}}$ of $5093 \mathrm{GM}$ $(800 \mathrm{~nm})^{[43]}$ and material suitable for white organic lightemitting diodes (WOLEDs). ${ }^{[44]}$ Further modification of the diazine V-shaped chromophores can be achieved by linking topology, ${ }^{[45]}$ ketonization (e.g., pyrimidone), ${ }^{[46]}$ fusing with an additional (hetero)aromatic ring (e.g., quinazoline, naphthyridine, bipyridine, hexaazatriphenylene - HAT) ${ }^{[47]}$ and quaternization. The last approach leads to cationic chromophores, such as pyridinium $\mathbf{2 4},{ }^{[48]}$ quinolizinium $\mathbf{2 5},{ }^{[49]}$ bipyridinium 26, ${ }^{[50]}$ or azacyanines 27 (Figure 11). ${ }^{[51]}$

In general, $\mathrm{N}$-quaternization of azines to azinium improves its electron-withdrawing ability, which subsequently enhances the D-A interaction (ICT). It further makes the

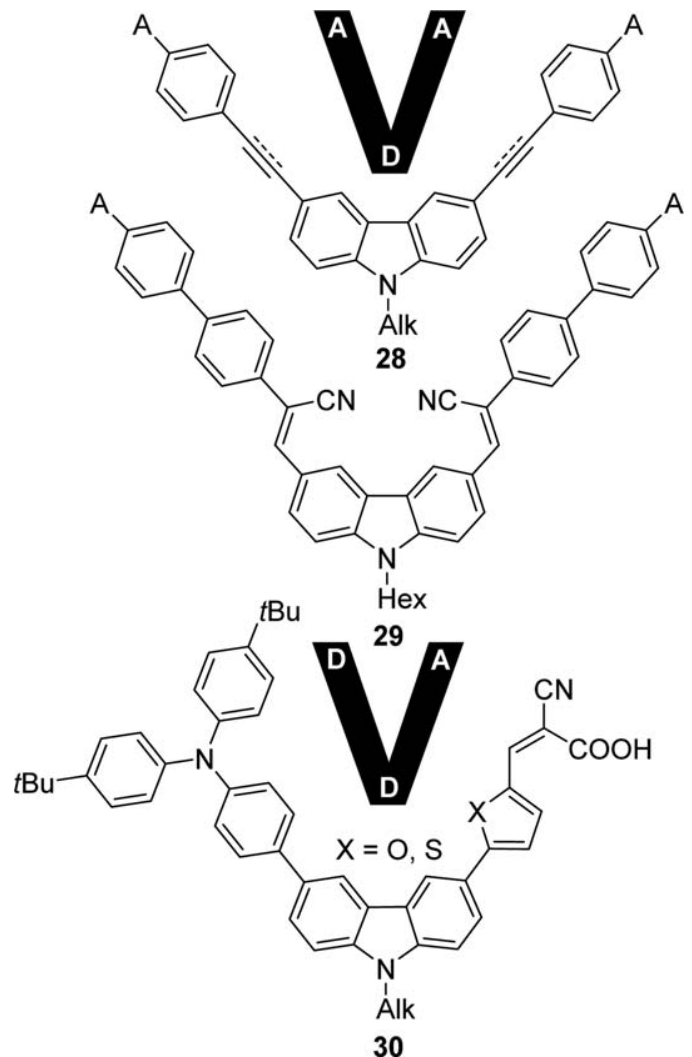

Fig. 12. Carbazole-derived V-shaped push-pull molecules for NLO and DSSC applications.

chromophore crystalline, soluble in polar solvents (hydrophilic), and improves its thermal stability. ${ }^{[52]}$ Hence, in contrast to azine analogues, azinium chromophores generally possess bathochromically shifted absorption and emission maxima, lower HOMO-LUMO gaps, and larger optical nonlinearities (e.g., large 2PA activity and strong fluorescence of 25 and 27).

In addition to the aforementioned six-membered heterocycles, V-shaped push-pull molecules were also built on some five-membered heteroaromatic compounds, such as carbazole, with a central pyrrole moiety. In contrast to electron-poor azine and azinium moieties, carbazole is employed as a central electron donor commonly equipped with two branches at positions C3/C6. For instance, Hsiue et al. investigated a series of carbazole V-shaped derivatives 28 (Figure 12) as twodimensional chromophores with large second-order molecular polarizabilities, which could be translated into macroscopic nonlinearity upon embedding the chromophore into polymeric matrix. ${ }^{[53]}$ Derivatives $\mathbf{2 8}$ with acetylenic spacers and peripheral formyl and nitro acceptors showed sufficient 2PA activity that allowed their use as two-photon polymerization initiators. ${ }^{[54]}$ Either symmetrically or asymmetrically substituted carbazole $\mathrm{D}-(\pi-\mathrm{A})_{2}$ molecules 29 and 30, bearing 


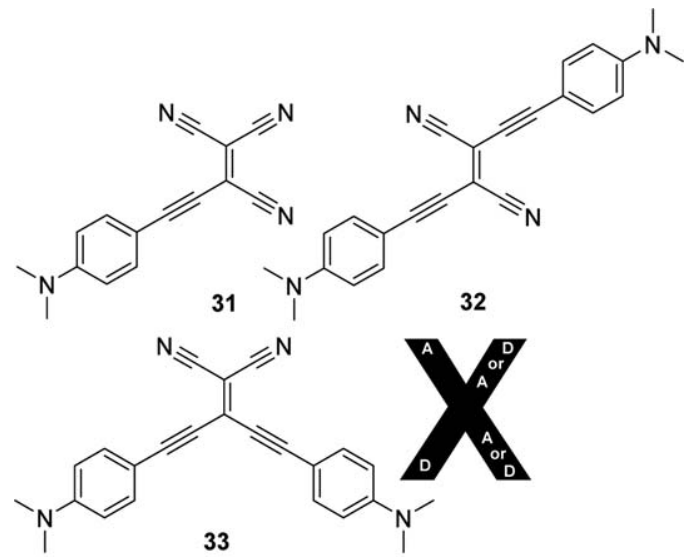

33

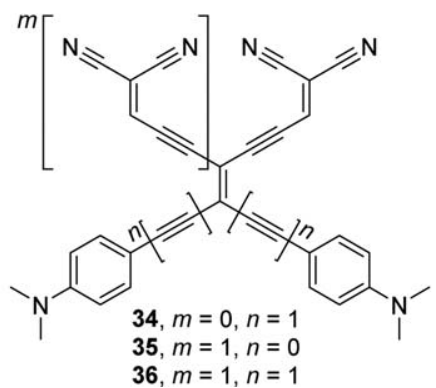

Fig. 13. Cyanoethynylethene (CEE) push-pull X-shaped chromophores with various number/arrangement of the donors and acceptors around the central ethene.

cyanoacrylic acid or rhodanine-3-acetic acid anchoring/ acceptor groups (A), also found application as dyes suitable for DSSCs. A DSSC device based on these organic materials showed overall conversion efficiencies of 2.37 and $6.68 \%$, respectively. ${ }^{[55]}$ In addition to optoelectronic applications, Shangguan et al. showed that carbazole V-shaped molecules with two peripheral benzo[ $[d]$ imidazole rings interact with G-quadruplex, and therefore, may act as potential chemotherapeutics. ${ }^{[56]}$

Similarly to carbazole D- $\pi-\mathrm{D}-\pi-\mathrm{A}$ derivatives 30, fivemembered thiadiazole was also utilized as a parent heteroaromatic $\pi$-backbone for the construction of $V$-shaped sensitizers for DSSCs. Employing various anchoring groups, a conversion efficiency of up to $4.12 \%$ can be achieved. ${ }^{[57]}$ Properly functionalized V-shaped oxazoles/thia(di)azoles or bisarylmaleimides possess mesomorphic properties or aggregation-induced enhanced emission (AIEE) and polymorphism-dependent fluorescence, as recently demonstrated by the groups of Leh$\operatorname{man}^{[58]}$ or Lin. ${ }^{[59]}$

\section{X-Shaped Molecules}

Push-pull molecules adopting an X-shape belong to traditional organic D- $\pi$-A systems. These molecules consist of four

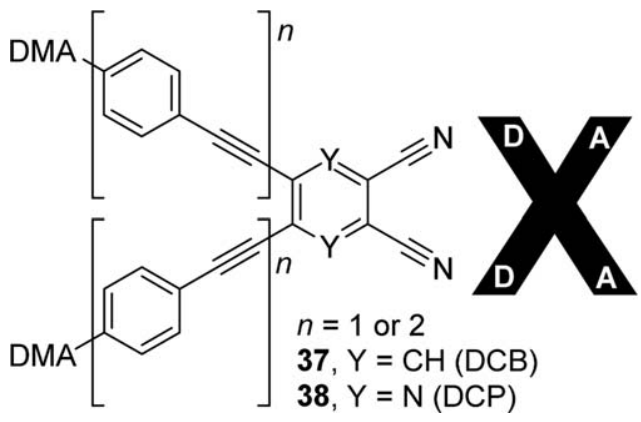

Fig. 14. DCB and DCP units in X-shaped CT chromophores.

branches interconnected by a central $\pi$-system. Typically, two branches bear electron acceptors and the other two are occupied by two donors in either parallel or antiparallel arrangements. The simplest central $\pi$-system is represented by a double bond. Diederich et al. have shown a new family of cyano-substituted chromophores 31-36 (Figure 13) called CEEs. ${ }^{[60]}$ Despite being simple in structure, these push-pull molecules based on former tetraethynylethenes (TEEs) proved to be tunable and very powerful electron acceptors, NLOphores, solvatochromic probes, and materials for optoelectronic applications. ${ }^{[61,2 \mathrm{a}]}$ For instance, chromophore $\mathbf{3 1}$ turned out to form crystalline thin films for nanoscale data recording, while the most branched and extended derivative 36 showed one of the highest third-order polarizabilities $\gamma_{\text {rot }}=45 \times 10^{-48} \mathrm{~m}^{5} \mathrm{~V}^{-2}$ (degenerate four-wave mixing at $1500 \mathrm{~nm}, \mathrm{CH}_{2} \mathrm{Cl}_{2}$ ).

Undoubtedly, 1,2,4,5-tetrasubstituted benzene is one of the most often employed central $\pi$-system in X-shaped molecules. The simplest X-shaped benzene $(\mathrm{D}-\pi)_{2}-\mathrm{B}-(\pi-\mathrm{A})_{2}$ cruciforms ( $\mathrm{B}$ is benzene) were pioneered by Nalwa et al. in the early 1990s as NLOphores capable of forming LangmuirBlodgett films. ${ }^{[62]}$ Since then, the design, synthesis, and applications of various benzene-derived X-shaped molecules can be considered as a burgeoning area. Their two-dimensional ICT, shape, arrangement, and thus, resulting peculiar (non)linear optical properties were also extensively investigated/predicted by quantum-chemical calculations. ${ }^{[63]}$ The pioneers of the modern era of X-shaped molecules are the groups of Marks, ${ }^{[64]}$ Buntz, ${ }^{[65]}$ and Haley. ${ }^{[66]}$ They developed a large number of cruciforms and have demonstrated their applicability as NLOphores, fluorophores, ion-sensing molecules, and so forth.

Recently, we introduced benzene-1,2-dicarbonitrile (dicyanobenzene (DCB)) as an electron-withdrawing moiety suitable for the construction of X-shaped push-pull molecules 37 with two DMA donors linked at positions C4 and C5 (Figure 14). ${ }^{[67]}$ These chromophores were further compared with isolobal pyrazine derivatives $\mathbf{3 8}$ bearing a pyrazine-2,3dicarbonitrile acceptor (dicyanopyrazine (DCP)). ${ }^{[68]}$ It was shown that heteroaromatic pyrazine acceptors imparted 

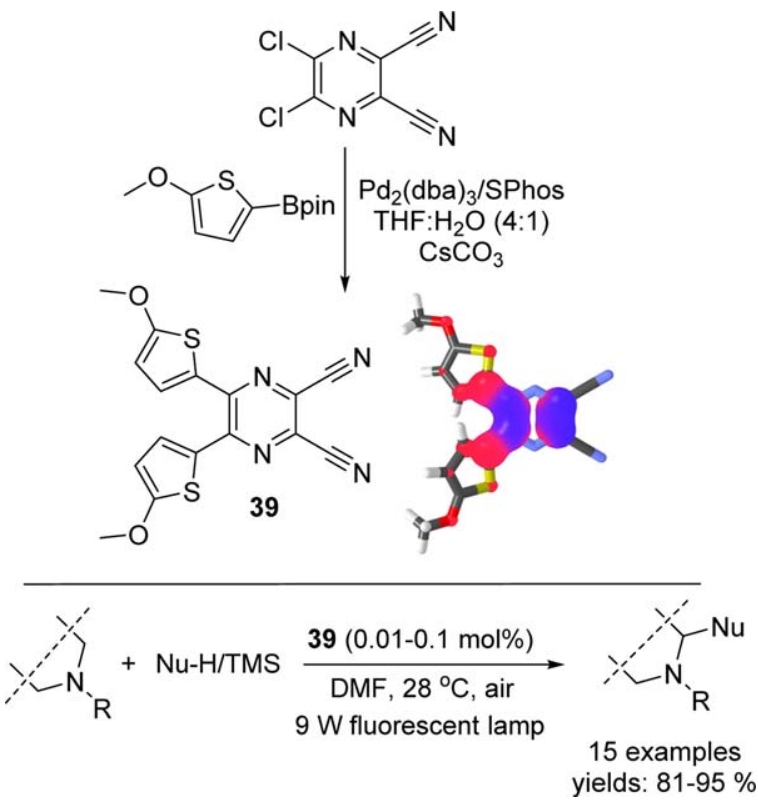

Scheme 2. Synthesis, molecular structure, and HOMO (red)/LUMO (blue) localizations in photoredox catalyst 39 and its application in CDC reaction.

stronger ICT than aromatic benzene, as indicated by the narrowed HOMO-LUMO gap, bathochromically shifted longest-wavelength absorption maxima, and higher quinoid character. However, further property tuning has been carried out through a systematic extension of the $\pi$-system by various combinations of acetylenic and 1,4-phenylene units, ${ }^{[69]}$ which revealed that, especially for the most extended molecules $(n=2)$, the optical nonlinearities of $37 / 38$ were dictated not only by the electron-withdrawing power of the DCB and DCP units, but gradually also by the length, composition, and planarity of the $\pi$-system. Hence, the most extended chromophores 37 with the DCB unit showed higher second-harmonic generation (SHG) responses than isolobal DCP chromophores 38 (e.g., 3.2/3.0 or 4.9/3.1 $\mathrm{pm} \mathrm{V}^{-1}$ ). ${ }^{[68]}$

Due to their optical and redox properties, selected dicyanopyrazines $\mathbf{3 8}$ were also envisaged as materials capable of undergoing photoinduced single electron transfer (SET). Upon modification of the electron-donating part with 5methoxythienyl substituents and optimization of its synthesis, a very efficient photoredox catalyst 39 has been developed (Scheme 2). ${ }^{[70]}$ Its absorption maxima of $448 \mathrm{~nm}$, band gap of $2.82 \mathrm{eV}$, and high ground-state dipole moment of $18.26 \mathrm{D}$ proved to be well-balanced for the SET mechanism involved in the cross-dehydrogenative coupling (CDC) reaction. The high catalytic activity of 39 and scope of this reaction have been demonstrated on substituted tetrahydroisoquinolines and other amines and various nucleophiles (Scheme 2), as well as in photocatalytic oxidations, oxidative hydroxylations, and reductive dehalogenations. These reactions did not require

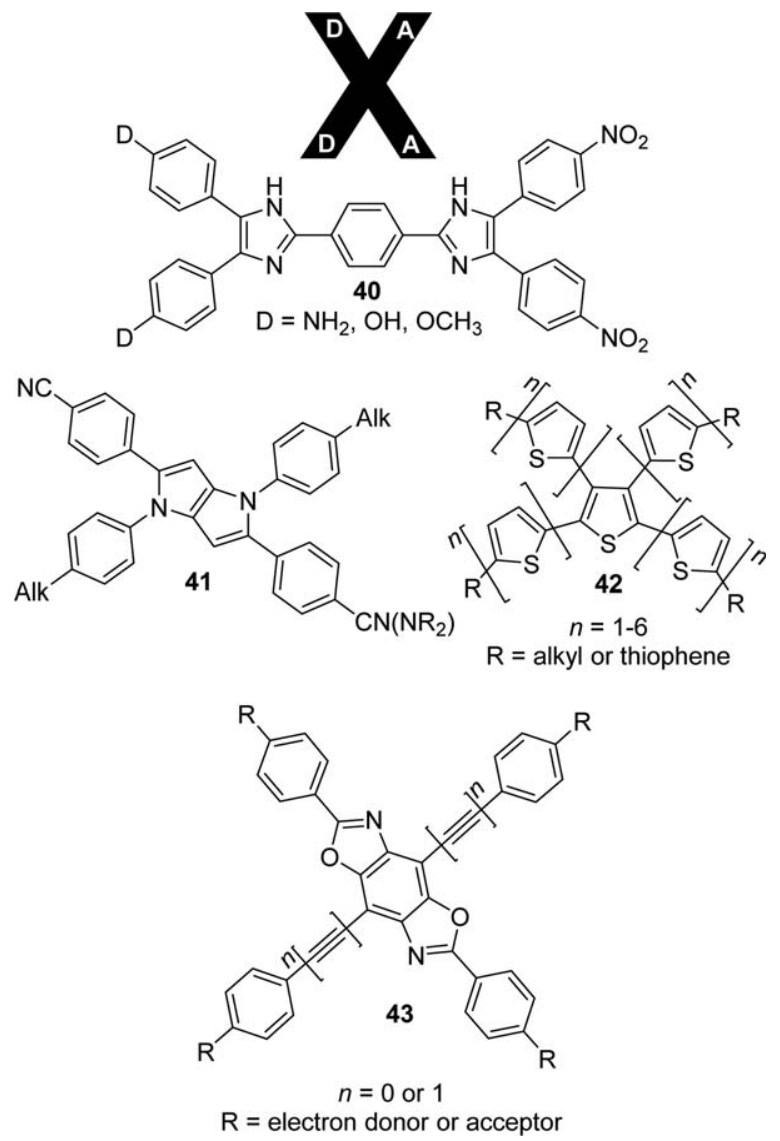

Fig. 15. Imidazole, pyrrolo[3,2-b]pyrrole, thiophene, and benzobisoxazole as a central $\pi$-cores for X-shaped molecules.

high-power light sources, long reaction times, air exclusion, or other special precautions, but provided the desired products in high yields, while the amount of $\mathbf{3 9}$ was less than 0.1 mol\% and even $0.01 \%$, which represents the lowest catalyst loading in current photoredox organocatalysis. Moreover, the high catalytic performance of 39 and utilization of itaconimide as a nucleophile in the CDC allowed the chemoselective control of radical cascade reactions (addition-cyclization, addition-elimination, addition-coupling, and addition-protonation), providing direct access to four new types of tetrahydroisoquinoline derivatives. ${ }^{[71]}$

DCP-derived molecules similar to $\mathbf{3 8}$ incorporated into a polymeric backbone were also investigated as thermally stable multi-ICT chromophores by Ye et al. ${ }^{[72]}$ In addition to parent six-membered (hetero)aromates, X-shaped chromophores can also be built on five-membered heterocycles, such as imidazole (40) or fused pyrrolo[3,2-b]pyrroles (41; Figure 15). Two reversely disubstituted imidazoles linked by 1,4-phenylene moiety in $\mathbf{4 0}$ adopted the $\mathrm{X}$ shape and were successfully applied as NLOphores upon incorporation into a polymer (PI or PMMA), achieving good nonlinearity-transparency- 


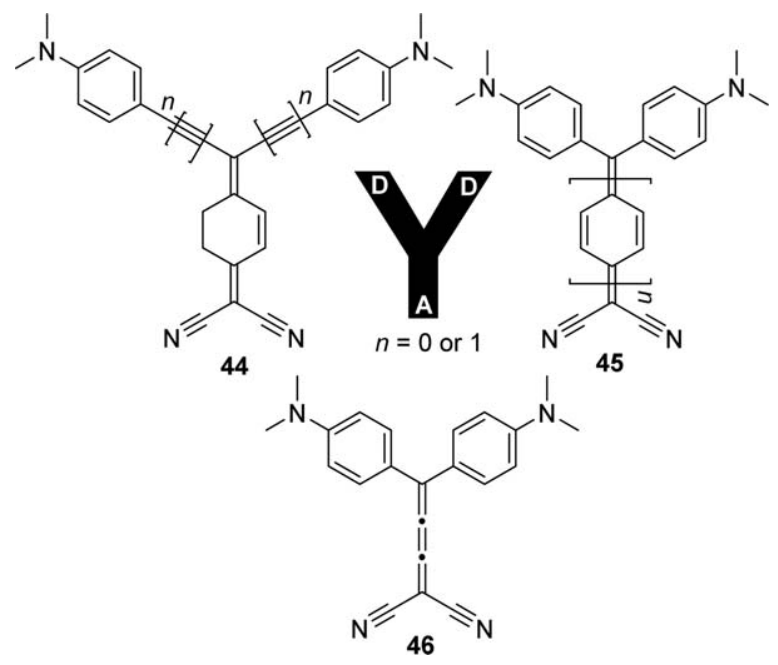

Fig. 16. Quinoid and cumulenic chromophores 44-46.

thermal stability trade-off. ${ }^{[73]}$ Very recently, Gryko et al. showed a modular synthetic approach towards tetraarylpyrrolo[3,2-b] pyrroles (41, TAPPs) with four $\pi$-branches bearing a $\mathrm{CN}$ acceptor or eventually an amino donor. ${ }^{[74]}$ These new $\pi$-conjugated materials showed appreciable fluorescent and two-photon absorbing properties. Tetrasubstituted thiophenes, especially those with an oligomeric structure, such as $\mathbf{4 2}$, proved to be electroactive materials with perspective applications in organic solar cells. ${ }^{[75]}$

The central $\pi$-system of X-shaped molecules can be further extended to fused (hetero)aromatic compounds, such as benzobisoxazoles, to form typical cruciforms 43 . These molecules, mostly investigated by Nuckolls et al. ${ }^{[76]}$ and Miljanić et al., ${ }^{[77]}$ were applied in molecular electronics or as fluorophores/fluorescent sensors.

To finish the series of X-shaped molecules, we have to mention that the $\mathrm{X}$ arrangement can also be achieved using fused aromatic compounds, such as naphthalene, ${ }^{[78]}$ anthracene, ${ }^{[79]}$ pyrene, ${ }^{[80]}$ or even more extended $\pi$-cores. ${ }^{[81]}$ The modern applications of these larger systems profit mainly from their large emissive and semiconducting character, and therefore, range from fluorophores, 2PAs, and OLEDs to OFETs.

\section{Y-Shaped Molecules}

Similarly to X-shaped molecules, Y-shaped push-pull chromophores constitute a large family of molecules, which can be constructed on a variety of $\pi$-scaffolds. Due to their shape and arrangement, they are often referred to as tripodal or octupolar. Nevertheless, in this section, we focus on selected Y-shaped molecules with the $\pi$-system built on multiple bonds, fivemembered heterocycles, triphenylamine (TPA), azines, and some other related central moieties. The Y-shaped systems

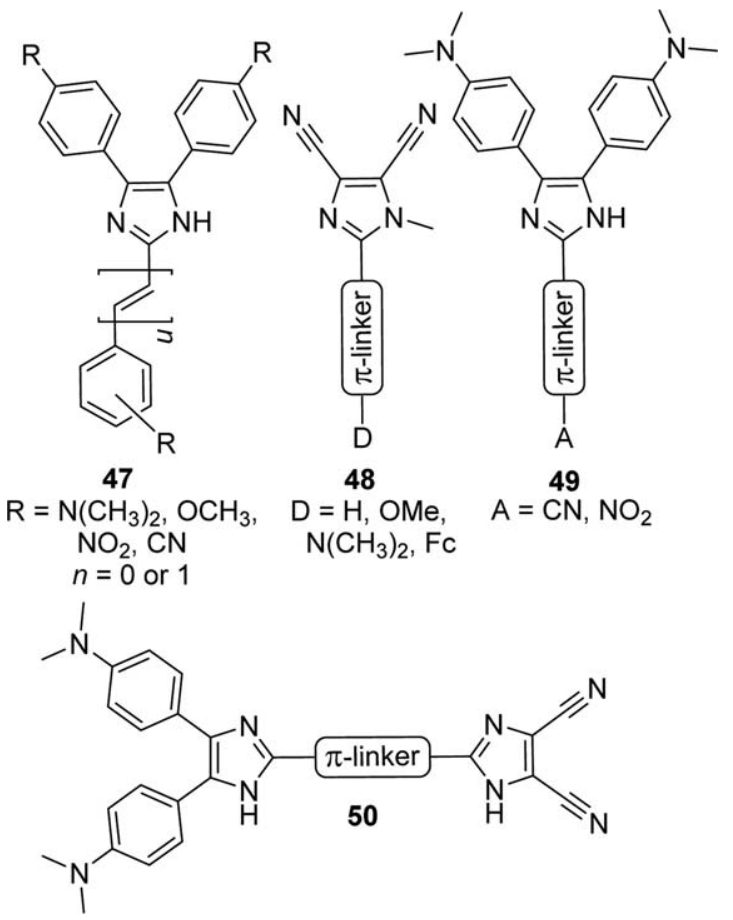

Fig. 17. Imidazole-derived Y-shaped push-pull chromophores 47-50 with various arrangements of electron acceptors and donors around the imidazole central core.

based on a combination of multiple bonds are frequently related to $\mathrm{V}(\mathrm{X})$-shaped molecules. For instance, semior expanded quinoids 44 and $45 ;^{[82]}$ buta-1,2,3-triene 46 (Figure 16); ${ }^{[83]}$ and donor-acceptor $4 H$-pyran-4-ylidene derivatives, such as $\mathbf{2 2}$ (Figure 10), ${ }^{[39 \mathrm{e}-\mathrm{g}, 42 \mathrm{~b}]}$ were investigated as proaromatic and proacetylenic chromophores with exceptionally small HOMO-LUMO gaps, as well as nonracemic NLOphores and fluorophores.

In addition to unsaturated hydrocarbon $\pi$-backbones in 44 and 45, we started our research on $Y$ shapes with heteroaromatic $1 H$-imidazole. ${ }^{[6]}$ The first series of push-pull molecules 47 (Figure 17) was built on simple lophine (2,4,5-triphenylimidazole). ${ }^{[84]}$ Subsequently, we focused on imidazole-4,5dicarbonitrile (dicyanoimidazole (DCI)) as a five-membered electron acceptor related to DCP. Despite its lower electronwithdrawing ability than DCP, DCI-derived molecules $\mathbf{4 8}$ were easy to synthesize and turned out to be suitable model push-pull chromophores for fundamental structure-property relationships studies. ${ }^{[85]}$ Both extension and branching of the $\pi$-system, as well as variation of the electron donor $\mathrm{D}$, were thoroughly and systematically evaluated. ${ }^{[1]}$

Chromophores 49 represent the opposite arrangement of electron donors around the central imidazole core to that in 48. ${ }^{[86]}$ In 49 , positions C4 and C5 are occupied by DMA electron donors, whereas the acceptor is placed at $\mathrm{C} 2$ separated by 

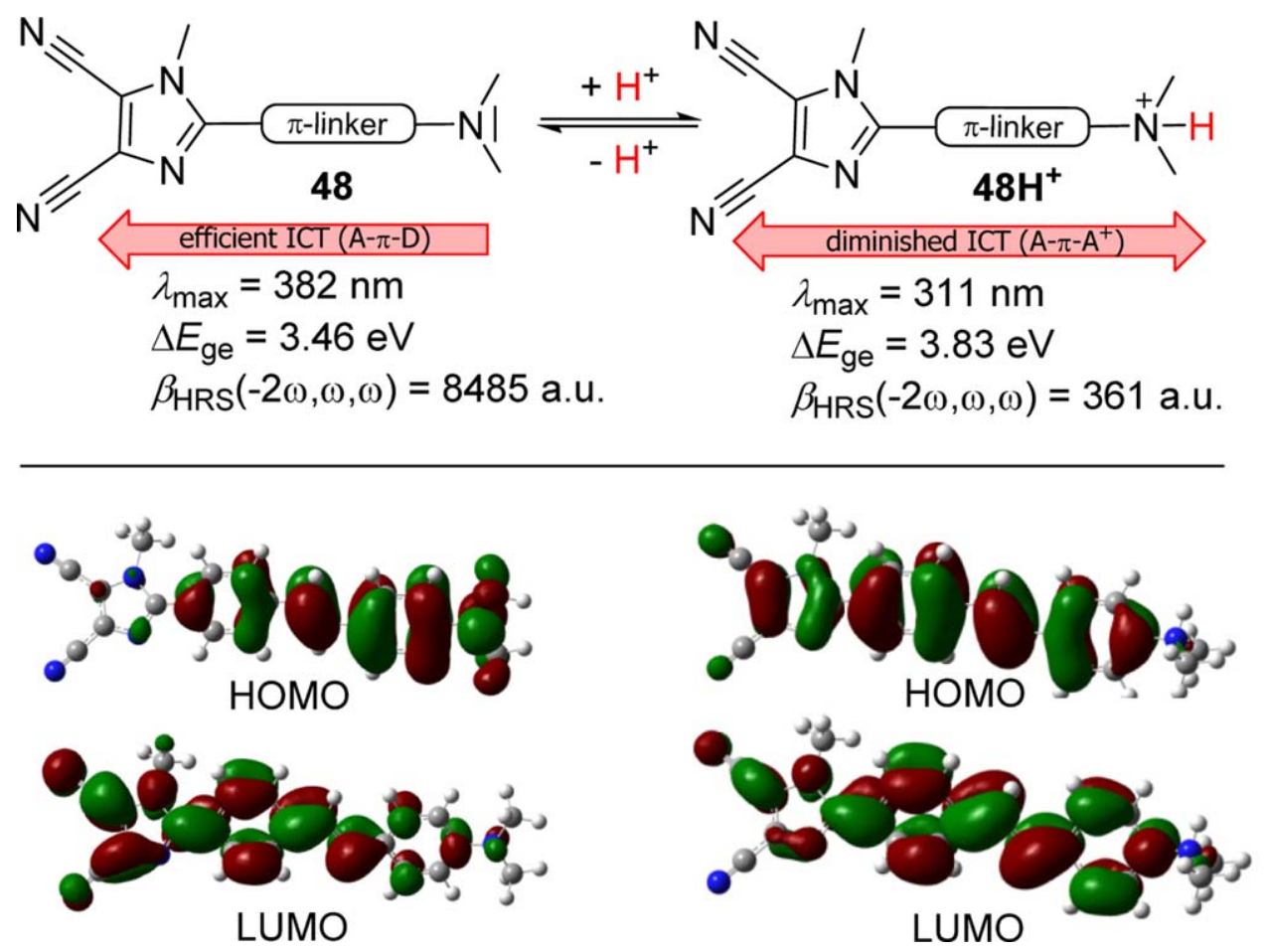

Scheme 3. The pH-triggered NLO switching of $N, N$-dimethylamino-substituted DCI chromophores 48 ( $\pi$-linker $=$ stilbenyl).

an additional linker. It turned out that $1 H$-imidazole was more polarizable with ICT transmitting from $\mathrm{C} 4 / \mathrm{C} 5$ to $\mathrm{C} 2$ rather than vice versa. Hence, our further synthetic efforts were directed towards a combination of both imidazole moieties to afford bisimidazoles $\mathbf{5 0}$ bearing electron-releasing 4,5-bis[4( $N, N$-dimethylamino)phenyl]imidazole and the DCI acceptor. ${ }^{[87]}$ Optoelectronic properties of imidazole derivatives 47-50 were further studied by electrochemistry, absorption/ emission spectra, and SHG experiments completed by DFT calculations. ${ }^{[88]}$ Whereas the DCI chromophores $\mathbf{4 8}$ bearing $\mathrm{N}, \mathrm{N}$-dimethylamino donor $\mathrm{D}$ were used as $\mathrm{pH}$-triggered NLO switches (Scheme 3) ${ }^{[89]}$ push-pull systems 48 bearing a double bond (styrene and stilbene $\pi$-linkers) underwent reversible $\mathrm{E} \rightarrow \mathrm{Z}$ photoisomerization. ${ }^{\left[{ }^{[0]}\right.}$ As can be seen in Scheme 3, simple protonation taking place exclusively on the amino donor can diminish the ICT in $\mathbf{4 8}$, which is reflected by the hypsochromically shifted absorption maxima $\left(\Delta \lambda_{\max }=\right.$ $71 \mathrm{~nm}$ ), high contrast of the NLO response between $\mathbf{4 8}$ and $\mathbf{4 8} \mathbf{H}^{+}$(23.5), and increased differences between the HOMO and LUMO $\left(\Delta E_{\mathrm{ge}}\right)$ and their distributions along the $\pi$-system (no charge separation upon protonation).

On the contrary, imidazole chromophores 49 with two DMA units showed significant light emission as a response to applied electric field, and therefore, were used as promising active materials for OLEDs. ${ }^{[91]}$
Since the pioneering work of Moylan et al., ${ }^{[92]}$ imidazole ${ }^{[93]}$ and thiazole ${ }^{[94]}$ become standard five-membered heterocyclic moieties widely used for the construction of Y-shaped chromophores, which were mainly utilized as robust NLOphores, fluorophores, chemosensors, and emissive materials. Thiazole proved to be more polarizable than oxazole or imidazole, and therefore, fused thiazole and related derivatives are considerably investigated as novel central $\pi$-conjugated scaffolds for Y-shaped molecules. ${ }^{[95]}$

TPA is another scaffold and central electron donor widely employed in the construction of centrifugal Y-shaped molecules. Tripodal push-pull TPA derivatives are increasingly popular as 2PAs, semiconducting materials, fluorophores, biosensors, and dyes for DSSCs. ${ }^{[96]}$ Despite recent progress made in understanding the $2 \mathrm{PA}$ process in organic push-pull systems, ${ }^{[13]}$ chromophores 51 (Figure 18) with variable peripheral cyano acceptor groups and moieties were designed as model tripodal push-pull molecules to systematically elucidate structure-2PA property relationships for TPA derivatives. ${ }^{[97]}$ Electron-withdrawing behavior, structure, number of $\mathrm{CN}$ groups, and their mutual orientation within the acceptor moiety, as well as extension and composition of the $\pi$-bridge have influenced the 2PA properties of $\mathbf{5 1}$ most significantly. In a subsequent paper, we also systematically studied branching and solvent effects on the 2PA activity of selected derivatives 
51 (according to the number of R substituents). ${ }^{[98]}$ It turned out that, when going from linear to quadrupolar systems, the 2PA activity increased most significantly, whereas a change

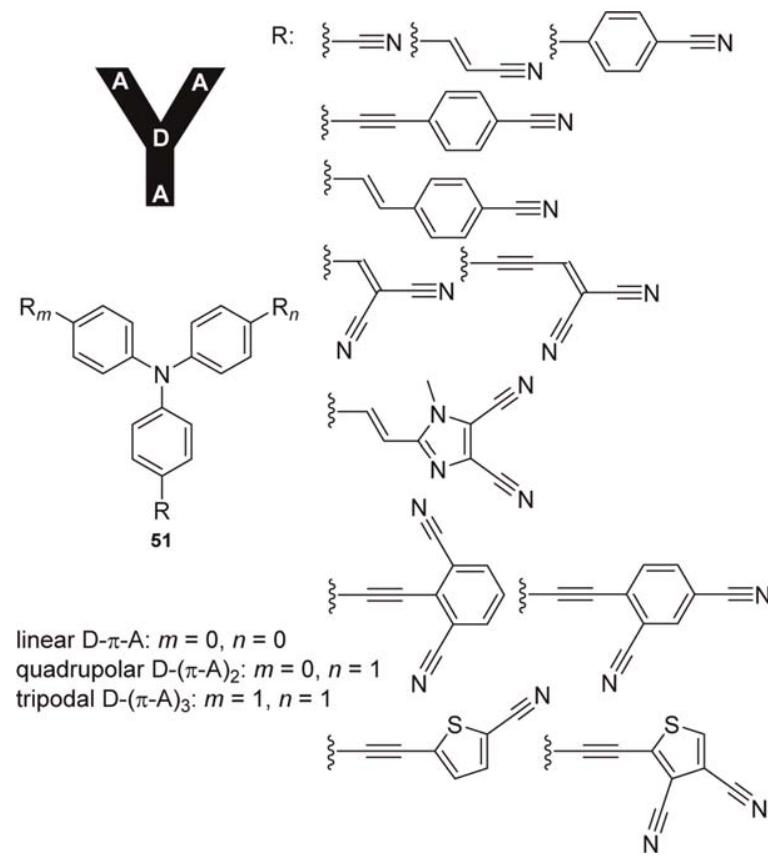

Fig. 18. TPA derivatives 51 with systematically altered peripheral (poly)cyano-substituted acceptor moieties. from quadrupolar to tripodal arrangements had a diminished effect. However, both effects are more or less pronounced, depending on the solvent used.

The TPA core can also be conveniently equipped with heteroaromatic diazine acceptor units (pyrimidine, pyrazine,

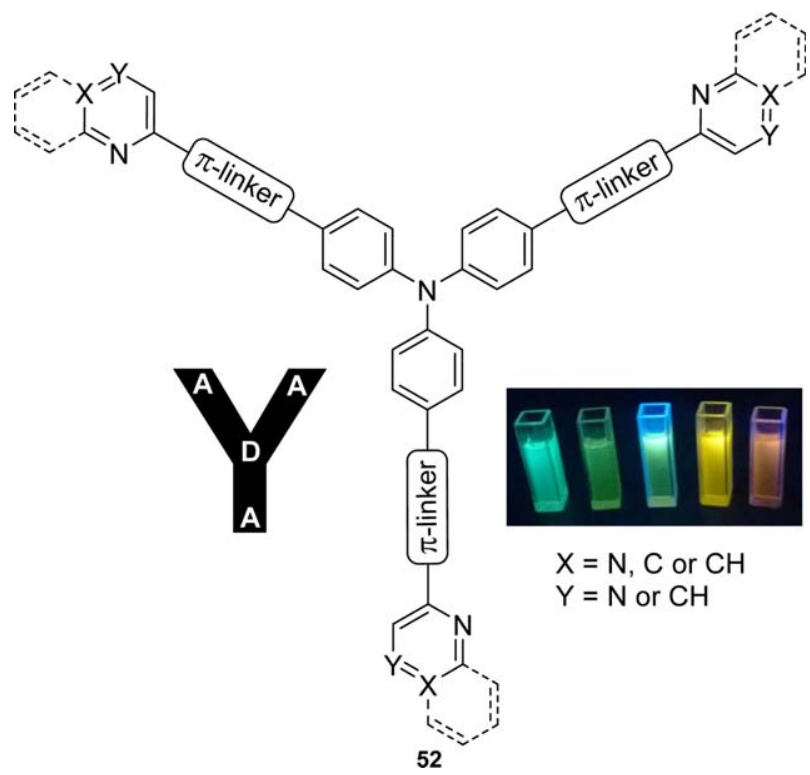

Fig. 19. Tripodal derivatives bearing peripheral diazine acceptors and their solvatochromism.

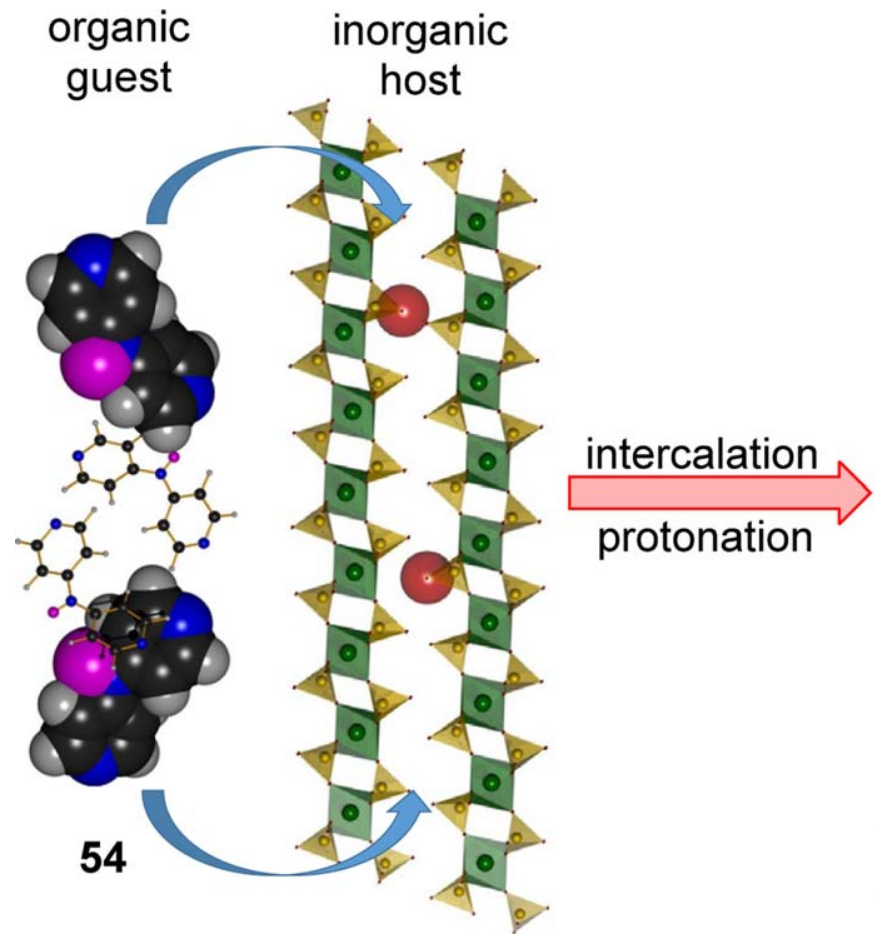

\section{inorganic-organic}

hybrid

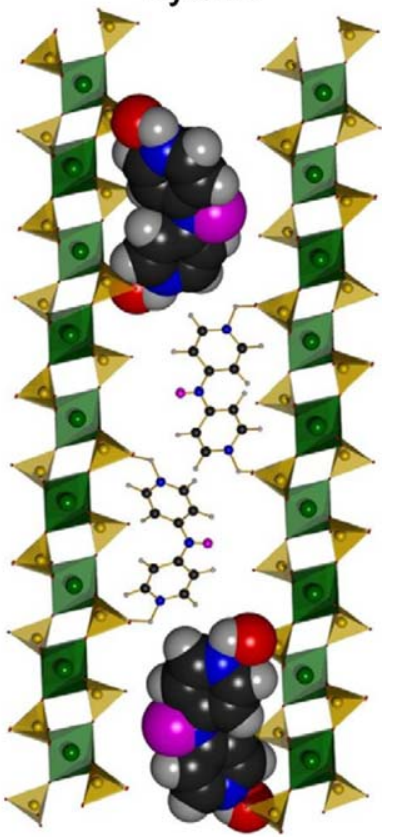

Scheme 4. Schematic representation of the intercalation process of $\mathbf{5 4}$ into layered inorganic hosts. 
and quinoxaline) as in 2PAs 52 (Figure 19) with strong emission solvatochromism. ${ }^{[99]}$

Based on a successful approach of improving the electron-withdrawing ability of pyridine acceptors through protonation/quaternization (see above), we have envisaged that pyridine-terminated TPA derivatives represent an ideal model of chromophores bearing peripheral basic centers,<smiles>[X]c1ccc(N)cc1</smiles><smiles>[X]c1ccc(Nc2ccccc2)cc1</smiles>

53, $\mathrm{X}=\mathrm{N}$<smiles>[X]c1ccc(C(C=C)=CC)cc1</smiles><smiles>[Y]c1ccc(-c2ccc(N(c3ccccc3)c3ccc(-c4ccc([Y4])cc4)cc3)cc2)cc1</smiles>

Fig. 20. Molecular structures and X-ray analysis of aminopyridine and TPA derivatives 53-56 with various spatial arrangements. allowing their intercalation into acid layered materials (Scheme 4). ${ }^{[52,100]}$

Starting from linear 4-aminopyridine $\mathbf{5 3}$, we have prepared quadrupolar di- and tripodal tripyridylamines $\mathbf{5 4}$ and 55, extended TPA derivative 56, and their $\mathrm{N}$-methyl analogues (Me; Figure 20). Despite being simple in the structure, tripyridylamine $\mathbf{5 5}$ has been prepared for the first time; X-ray analysis showed an almost perfectly symmetrical structure. The extent and character of the intercalation process of 53-55 (Scheme 4) into alpha modification of zirconium hydrogen phosphate (ZrP), zirconium 4-sulfophenylphosphonate (ZrSPP), and gamma modification of titanium hydrogen phosphate (TiP) were studied by various methods. The following features should be stressed herein: 1 ) the ratio of the amount of intercalated $\mathbf{5 3 - 5 5}$ was $6: 3: 2$, which was inversely proportional to the charge generated at each aminopyridine guest $(1: 2: 3) ; 2) \mathbf{5 3}$ 55 underwent (partial) protonation during intercalation, depending on the number of basic centers and acidity of the host; 3) improved thermal and chemical resistance of the organic guest upon encapsulation into inorganic host; 4) protonation improved the ICT, redshifted the $\lambda_{\max }$, and reduced the $\Delta E$; and 5) supramolecular organization of 53-55 in the layered materials further enhanced their SHG responses (compare the data shown in Table 2 for 53-55, Me53-Me55, and their intercalates). Thus, intercalation is a very useful strategy to achieve inorganic-organic hybrid materials with tailored (NLO) properties.

A replacement of the central nitrogen atom in TPA by phosphorus or boron leads to phosphane oxide- or borane-

Table 2. Properties and optical nonlinearities of 53-55, Me53-Me55, and their intercalates.

\begin{tabular}{|c|c|c|c|c|c|}
\hline Comp. & $\begin{array}{c}\lambda_{\max } \\
{[\mathrm{nm}(\mathrm{eV})]^{[\mathrm{a}]}}\end{array}$ & $\begin{array}{c}\Delta E \\
{[\mathrm{eV}]^{[\mathrm{b}]}}\end{array}$ & $\begin{array}{c}\mu \\
{[\mathrm{D}]^{[\mathrm{b}]}}\end{array}$ & $\begin{array}{l}\beta(-2 \omega ; \omega, \omega) \\
{\left[10^{-30} \mathrm{esu}\right]^{[\mathrm{c}]}}\end{array}$ & $\begin{array}{c}d_{\text {eff }} \\
{[\mathrm{pm} / \mathrm{V}]^{[\mathrm{d}]}}\end{array}$ \\
\hline 53 & $248(5.00)$ & 5.86 & 5.36 & 1.06 & 1.34 \\
\hline 54 & $293(4.23)$ & 4.95 & 3.64 & 1.44 & 1.56 \\
\hline 55 & $307(4.04)$ & 4.72 & 0.02 & 0.01 & 0.35 \\
\hline Me53 & $271(4.58)$ & 5.40 & 0.58 & 1.37 & 1.42 \\
\hline Me54 & $326(3.80)^{[\mathrm{e}]}$ & 4.54 & 0.16 & 2.61 & 1.67 \\
\hline Me55 & $323(3.84)^{[\mathrm{e}]}$ & 4.41 & 0.06 & 0.13 & 1.04 \\
\hline ZrSPP-53 & $263(4.71)$ & - & - & - & 1.78 \\
\hline ZrSPP-54 & $317(3.91)$ & - & - & - & 1.89 \\
\hline ZrSPP-55 & $323(3.84)$ & - & - & - & 1.21 \\
\hline ZrP-53 & $260(4.77)$ & - & - & - & 1.67 \\
\hline ZrP-54 & $297(4.18)$ & - & - & - & 1.72 \\
\hline $\mathrm{ZrP}-55$ & $305(4.06)$ & - & - & - & 1.45 \\
\hline TiP-53 & $261(4.75)$ & - & - & - & 2.01 \\
\hline TiP-54 & $305(4.07)$ & - & - & - & 2.21 \\
\hline TiP-55 & $315(3.94)$ & - & - & - & 1.56 \\
\hline
\end{tabular}

[a] Measured in the solid state $\left(\mathrm{Al}_{2} \mathrm{O}_{3}\right)$. [b] DFT calculations (at the B3LYP/6-311++G(2d,p)//B3LYP/6-311++G(2d,p) level) in DMF. [c] DFT calculations (at the B3LYP/6-311++G(2d,p)//B3LYP/6-311++G(2d,p) level) in vacuum at $1064 \mathrm{~nm}$. [d] Measured in oligoetheracrylate at $1064 \mathrm{~nm}( \pm 0.15 \mathrm{pm} / \mathrm{V})$. [e] Shoulder at $392(3.16) \mathrm{nm}(\mathrm{eV})$. 


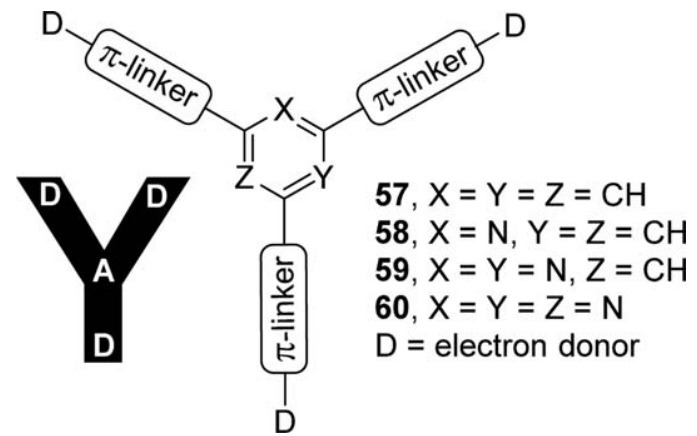

Fig. 21. Centripetal Y-shaped molecules 57-60 based on various (hetero)aromatic moieties.

derived tripodal push-pull molecules with noticeable NLO activity. ${ }^{[101]}$ However, these molecules are complicated to prepare and generally suffer from lower stability than TPA.

The centrifugal arrangement of TPA derivatives can be reversed to centripetal if electron-deficient cores, such as $1,3,5-$ trisubstituted benzene $57,{ }^{[102]}$ 2,4,6-trisubstituted pyridine 58, ${ }^{[103]}$ and pyrimidine 59, ${ }^{[104]}$ are employed (Figure 21). However, the most widely employed central electron acceptor for star-shaped centripetal push-pull molecules is undoubtedly triazine $\mathbf{6 0}{ }^{[105]}$ Increasing the number of heteroatoms within the central ring imparts stronger ICT into the branches, and therefore, chromophores $\mathbf{5 7 - 6 0}$ are increasingly polarized. The applications range from second-order NLOs, 2PAs, liquid crystals, photovoltaics, and OLEDs to molecules showing aggregation-induced emission.

\section{Conclusion}

We have attempted to demonstrate herein that the recent design of organic push-pull molecules can be inspired by letters of the alphabet. This article intends to show how heterogeneously organic chemists can trifle with known patterns to combine them into novel types of $\pi$-conjugated molecules with the properties tailored to satisfy numerous requests of materials chemists. Various extraordinary arrangements, in particular H-, L-, T-, V-, X-, and Y-shapes, can be revealed in the current literature. We focused our research activity especially towards T-, X-, and Y-shaped molecules, which were discussed in more detail. The parent $\pi$-conjugated moieties utilized for the construction of these letter-shaped D- $\pi$-A chromophores involve (hetero)aromatic compounds such as indan-1,3-dione, olefinic and acetylenic scaffolds, benzene, pyrazine, imidazole, pyridine, and TPA. These units are most often equipped with peripheral acceptors, donors, and eventually an additional $\pi$-linker, but the electron-releasing or -withdrawing moieties can also be incorporated directly into the chromophore $\pi$-backbone. In our opinion, the most fascinating feature of push-pull molecules is their tunable properties. Hence, organic CT chromophores can be directed towards second-order NLOs, two-photon absorption, NLO switches, fluorophores, OLEDs, OFETs, DSSCs, photocatalysis, intercalation, and so forth. The current push-pull molecules can surely be considered as old friends with a new look and applications. In the near future, we eagerly expect novel lettershaped push-pull molecules to gradually fill the whole alphabet.

\section{Acknowledgements}

This work has received funding from the European Research Council (ERC) under the European Union's Horizon 2020 research and innovation program (grant agreement no. [638857]). We would like to express our sincere thanks to our colleagues and collaborators for their outstanding support, contribution, and enthusiasm. Without their generous support, this multidisciplinary research would not be possible (O. Pytela, J. Kulhánek, M. Ludwig, J. Macák, T. Mikysek, N. Almonasy, V. Zima, M. Danko, A. Růžička, Z. Růžičková, F. Diederich, M. Kivala, I. Kityk, W. Kuznik, S. Achelle, A. Barsella, B. Champagne, M. Fakis, Z. Jiang).

\section{REFERENCES}

[1] F. Bureš, RSC Adv. 2014, 4, 58826-58851.

[2] a) P. D. Jarowski, Y. Mo, Chem. Eur. J. 2014, 20, $17214-$ 17221; b) M. Kivala, F. Diederich, Acc. Chem. Res. 2009, 42, 235-248; c) J. Roncali, Macromol. Rapid. Commun. 2007, 28, 1761-1775; d) H. Meier, Angew. Chem. Int. Ed. 2005, 44, 2482-2506; e) H. A. M. van Mullekom, J. A. J. M. Vekemans, E. E. Havinga, E. W. Meijer, Mater. Sci. Eng. 2001, 32, 1-40; f) J. Roncali, Chem. Rev. 1997, 97, 173205.

[3] a) S. Achelle, N. Plé, A. Turck, RSC Adv. 2011, 1, 364-388; b) S. Achelle, N. Plé, Curr. Org. Synth. 2012, 9, 163-187; c) A. Wild, A. Winter, F. Schlütter, U. S. Schubert, Chem. Soc. Rev. 2011, 40, 1459-1511.

[4] a) V. Malytskyi, J.-J. Simon, L. Patrone, J.-M. Raimundo, RSC Adv. 2015, 5, 354-397; b) K. Takimiya, I. Osaka, Chem. Rec. 2015, 15, 175-188.

[5] Handbook of Thiophene-Based Materials, Applications in Organic Electronics and Photonics, Vols. 1 and 2 (Eds.: I. F. Perepichka, D. F. Perepichka), Wiley, Chicester, 2009.

[6] a) J. Kulhánek, F. Bureš, Beilstein J. Org. Chem. 2012, 8, 25 49; b) F. Bureš, Chem. Listy 2013, 107, 834-842.

[7] K. Hübner, Chem. Unserer Zeit 2006, 40, 274-275.

[8] a) P. N. Prasad, D. J. Williams, Introduction to Nonlinear Optical Effects in Molecules \& Polymers, Wiley, New York, 1991; b) K. Y. Suponitsky, T. V. Timofeeva, M. Y. Antipin, Russ. Chem. Rev. 2006, 75, 457-496. 
[9] a) Special issue on Organic Electronics and Optoelectronics (Eds.: S. R. Forrest, M. E. Thompson): Chem. Rev. 2007, 107, 923-1386; b) special issue on Materials for Electronics (Eds.: R. D. Miller, E. A. Chandross): Chem. Rev. 2010, 110, 1-574; c) special issue on Molecular Electronics_From a Visionary Concept towards Reality (Ed.: M. Mayor): Chimia 2010, 64, 348-420.

[10] a) Y. Wu, W. Zhu, Chem. Soc. Rev. 2013, 42, 2039-2058; b) M. Liang, J. Chen, Chem. Soc. Rev. 2013, 42, 3453-3488; c) J. N. Clifford, E. Martínez-Ferrero, A. Viterisi, E. Palomares, Chem. Soc. Rev. 2011, 40, 1635-1646.

[11] a) A. Mishra, P. Bäuerle, Angew. Chem. Int. Ed. 2012, 51, 2020-2067; b) C. Duan, F. Huang, Y. Cao, J. Mater. Chem. C 2012, 22, 10416-10434; c) B. Walker, C. Kim, T.-Q. Nguyen, Chem. Mater. 2011, 23, 470-482.

[12] Y. Ohmori, Laser Photonics Rev. 2009, 4, 300-310.

[13] a) M. Pawlicki, H. A. Collins, R. G. Denning, H. L. Anderson, Angew. Chem. Int. Ed. 2009, 48, 3244-3266; b) G. S. He, L.-S. Tan, Q. Zheng, P. N. Prasad, Chem. Rev. 2008, 108, 1245-1330.

[14] G. Qian, Z. Y. Wang, Chem. Asian J. 2010, 5, 1006-1029.

[15] a) C.-Z. Zhang, C. Lu, J. Zhu, G.-Y. Lu, X. Wang, Z.-W. Shi, F. Liu, Y. Cui, Chem. Mater. 2006, 18, 6091-6093; b) C.-Z. Zhang, C. Lu, J. Zhu, C.-Y. Wang, G.-Y. Lu, C.-S. Wang, D.-L. Wu, F. Liu, Y. Cui, Chem. Mater. 2008, 20, 46284641; c) C.-Z. Zhang, J. Zhu, C. Lu. G.-Y. Lu, Y. Cui, Mater. Chem. Phys. 2009, 114, 515-517; d) C. Z. Zhang, G. Y. Lu, C. S. Wang, Chin. Chem. Lett. 2009, 20, 620-622; e) J. Zhu, C. Lu, Y. Cui, C. Zhang, G. Lu, J. Chem. Phys. 2010, 133, 244503; f) Z. Liu, G.-Y. Lu, J. Ma, J. Phys. Org. Chem. 2011, $24,568-577$.

[16] J.-P. Shi, D.-L. Wu, Y. Ding, D.-H. Wu, H.-W. Hu, G.-Y. Lu, Tetrahedron 2012, 68, 2770-2777.

[17] S. Cong, A. Zhang, F. Liu, D. Yang, M. Zhang, S. Bo, X. Liu, L. Qiu, Z. Zhen, RSC Adv. 2015, 5, 10497-10504.

[18] a) W. Wu, C. Ye, J. Qin, Z. Li, ChemPlusChem 2013, 78, 1523-1529; b) Z. Li, G. Qiu, C. Ye, J, Qin, Z. Li, Dyes Pigm. 2012, 94, 16-22; c) Z. Li, W. Wu, G. Yu, Y. Liu, C. Ye, J. Qin, Z. Li, ACS Appl. Mater. Interfaces 2009, 1, 856-863; d) Z. Li, Z. Li, C. Di, Z. Zhu, Q. Li, Q. Zeng, K. Zhang, Y. Liu, C. Ye, J. Qin, Macromolecules 2006, 39, 6951-6961.

[19] Y. Zhang, T. Han, S. Gu, T. Zhou, C. Zhao, Y. Guo, X. Feng, B. Tong, J. Bing, J. Shi, J. Zhi, Y. Dong, Chem. Eur. J. 2014, 20, 8856-8861.

[20] H. Akdas-Kilig, T. Roisnel, I. Ledoux, H. Le Bozec, New J. Chem. 2009, 33, 1470-1473.

[21] Y. Liu, F. Zhang, C. He, D. Wu, X. Zhuang, M. Xue, Y. Liu, X. Feng, Chem. Commun. 2012, 48, 4166-4168.

[22] X.-X. Wang, T. Tao, J. Geng, B.-B. Ma, Y.-X. Peng, W. Huang, Chem. Asian J. 2014, 9, 514-525.

[23] X. Zhao, K. Cao, H. Zhou, R. Lu, Opt. Mater. 2014, 36, 950-957.

[24] R. C. Lirag, H. T. M. Le, O. Š. Miljanić, Chem. Commun. 2013, 49, 4304-4306.
[25] R. Centore, S. Fusco, A. Peluso, A. Capobianco, M. Stolte, G. Archetti, H.-G. Kuball, Eur. J. Org. Chem. 2009, 35353543.

[26] P. Solanke, F. Bureš, O. Pytela, J. Kulhánek, Z. Padělková, Synthesis 2013, 45, 3044-3051.

[27] P. Solanke, F. Bureš, O. Pytela, M. Klikar, T. Mikysek, L. Mager, A. Barsella, Z. Růžičková, Eur. J. Org. Chem. 2015, 24, 5339-5349.

[28] A. Felouat, A. D’Aleó, A. Charaf-Eddin, D. Jacquemin, B. Le Guennic, E. Kim, K. J. Lee, J. Heun, Woo, J.-C. Ribierre, J. W. Wu, F. Fages, J. Phys. Chem. A 2015, 119, 6283-6295.

[29] N. Zhigang, L. Dachao, L. Dong, X. Dong, Z. Ying, S. Wei, L. Gaonan, Chem. Res. Chin. Univ. 2014, 30, 425-430.

[30] J. Geng, Y. Dai, X.-X. Wang, M.-Y. Hu, T. Tao, W. Huang, Tetrahedron 2015, 71, 654-662.

[31] Z.-H. Guo, T. Lei, Z.-X. Jin, J.-Y. Wang, J. Pei, Org. Lett. 2013, 15, 3530-3533.

[32] X. Lu, S. Fan, J. Wu, X. Jia, Z.-S. Wang, G. Zhou, J. Org. Chem. 2014, 79, 6480-6489.

[33] L. V. Brownell, K. A. Robins, Y. Jeong, Y. Lee, D.-C. Lee, J. Phys. Chem. C 2013, 117, 25236-25247.

[34] a) D.-C. Lee, K. Jang, K. K. McGrath, R. Uy, K. A. Robins, D. W. Hatchett, Chem. Mater. 2008, 20, 3688-3695; b) K. Jang, J. M. Kinyanjui, D. W. Hatchett, D.-C. Lee, Chem. Mater. 2009, 21, 2070-2076; c) K. Jang, A. D. Ranasinghe, C. Heske, D.-C. Lee, Langmuir 2010, 26, 13630-13636.

[35] a) T. Inouchi, T. Nakashima, M. Toba, T. Kawai, Chem. Asian J. 2011, 6, 3020-3027; b) T. Inouchi, T. Nakashima, T. Kawai, Asian J. Org. Chem. 2013, 2, 230-238; c) T. Inouchi, T. Nakashima, T. Kawai, J. Phys. Chem. A 2014, 118, 25912598.

[36] N. Noujeim, K. Zhu, V. N. Vukotic, S. J. Loeb, Org. Lett. 2012, 14, 2484-2487.

[37] a) A. C. Benniston, A. Harriman, S. L. Howell, P. Li, D. P. Lydon, J. Org. Chem. 2007, 72, 888-897; b) D. P. Lydon, P. Li, A. C. Benniston, W. McFarlane, R. W. Harrington, W. Clegg, Eur. J. Org. Chem. 2007, 1653-1658.

[38] a) K.-S. Moon, H.-J. Kim, E. Lee, M. Lee, Angew. Chem. Int. Ed. 2007, 46, 6807-6810; b) L. Liu, K-S. Moon, R. Gunawidjaja, E. Lee, V. V. Tsukruk, M. Lee, Langmuir 2008, 24, 3930-3936.

[39] a) C. R. Moylan, S. Ermer, S. M. Lovejoy, I.-H. McComb, D. S. Leung, R. Wortmann, P. Krdmer, R. J. Twieg, J. Am. Chem. Soc. 1996, 118, 12950-12955; b) C. Sissa, F. Terenziani, A. Painelli, R. B. Kanth Siram, S. Patil, J. Phys. Chem. B 2012, 116, 4959-4966; c) G. Koeckelberghs, L. De Groof, J. Pérez-Moreno, I. Asselberghs, K. Clays, T. Verbiest, C. Samyn, Tetrahedron 2008, 64, 3772-3781; d) R. Andreu, L. Carrasquer, J. Garín, M. J. Modrego, J. Orduna, R. Alicante, B. Villacampa, M. Allain, Tetrahedron Lett. 2009, 50, 2920-2924; e) R. Andreu, E. Galán, J. Garín, V. Herrero, E. Lacarra, J. Orduna, R. Alicante, B. Villacampa, J. Org. Chem. 2010, 75, 1684-1692; f) S.-S. P. Chou, C.-Y. Yu, Synth. Met. 2004, 142, 259-262; g) E. Gubbelmans, T. Verbiest, I. Picard, A. Persoons, C. Samyn, Polymer 2005, 46, $1784-1795$. 
[40] J. Kulhánek, F. Bureš, J. Opršal, W. Kuznik, T. Mikysek, A. Růžička, Asian J. Org. Chem. 2013, 2, 422-431.

[41] D. Jana, B. K. Ghorai, Tetrahedron 2012, 68, 7309-7316.

[42] a) S. Achelle, I. Nouira, B. Pfaffinger, Y. Ramondenc, N. Plé, J. Rodríguez-López, J. Org. Chem. 2009, 74, 3711-3717; b) S. Achelle, S. Kahlal, J.-Y. Saillard, N. Cabon, B. Caro, F. Robin-le Guen, Tetrahedron 2014, 70, 2804-2815; c) S. Achelle, J. R. Lopez, F. Bureš, F. Robin-le Guen, Dyes Pigm. 2015, 121, 305-311; d) S. Achelle, J. P. Malval, S. Aloise, A. Barsella, A. Spangenberg, L. Mager, H. Akdas-Kilig, J. L. Fillaut, B. Caro, F. Robin-le Guen, ChemPhysChem 2013, 14, 2725-2738.

[43] J.-P. Malval, S. Achelle, L. Bodiou, A. Spangenberg, L. C. Gomez, O. Soppera, F. Robin-le Guen, J. Mater. Chem. C 2014, 2, 7869-7880.

[44] S. Achelle, J. Rodrígez-López, N. Cabon, F. Robin-le Guen, RSC Adv. 2015, 5, 107396-107399.

[45] L. Skardziute, J. Dodonova, A. Voitechovicius, J. Jovaisaite, R. Komskis, A. Voitechoviciute, J. Bucevicius, K. Kazlauskas, S. Jursenas, S. Tumkevicius, Dyes Pigm. 2015, 118, 118-128.

[46] a) J. Dhuguru, C. Gheewala, N. S. Saleesh Kumar, J. N. Wilson, Org. Lett. 2011,13, 4188-4191; b) E. AdjayeMensah, W. G. Gonzalez, D. R. Bussé, B. Captain, J. Miksovska, J. N. Wilson, J. Phys. Chem. A 2012, 116, 86718677.

[47] a) S. Achelle, J. Rodríguez-López, F. Robin-le Guen, J. Org. Chem. 2014, 79, 7564-7571; b) J.-H. Huang, W.-H. Wen, Y.-Y. Sun, P.-T. Chou, J.-M. Fang, J. Org. Chem. 2005, 70, 5827-5832; c) F. Todescato, I. Fortunati, S. Carlotto, C. Ferrante, L. Grisanti, C. Sissa, A. Painelli, A. Colombo, C. Dragonettic, D. Roberto, Phys. Chem. Chem. Phys. 2011, 13, 11099-11109; d) R. Juárez, M. Ramos, J. L. Segura, J. Orduna, B. Villacampa, R. Alicante, J. Org. Chem. 2010, 75, 7542-7549.

[48] a) M. A. Ramirez, A. M. Cuadro, J. Alvarez-Builla, O. Castano, J. L. Andrés, F. Mendicuti, K. Clays, I. Asselbergh, J. J. Vaquero, Org. Biomol. Chem. 2012, 10, 1659-1669; b) M. A. Ramirez, T. Caneque, A. M. Cuadro, F. Mendicuti, K. Clays, I. Asselbergh, J. J. Vaquero, ARKIVOC 2011, iii, 140155.

[49] E. Maçôas, G. Marcelo, S. Pinto, T. Caneque, A. M. Cuadro, J. J. Vaquero, J. M. G. Martinho, Chem. Commun. 2011, 47, 7374-7376.

[50] B. J. Coe, J. Fielden, S. P. Foxon, J. A. Harris, M. Helliwell, B. S. Brunschwig, I. Asselberghs, K. Clays, J. Garín, J. Orduna, J. Am. Chem. Soc. 2010, 132, 10498-10512.

[51] M. Tasior, V. Hugues, M. Blanchard-Desce, D. T. Gryko, Asian J. Org. Chem. 2013, 2, 669-673.

[52] F. Bureš, D. Cvejn, K. Melánová, L. Beneš, J. Svoboda, V. Zima, O. Pytela, T. Mikysek, Z. Růžičková, I. V. Kityk, A. Wojciechowski, N. AlZayed, J. Mater. Chem. C 2016, 4 , 468-478.

[53] a) W.-J. Kuo, G.-H. Hsiue, R.-J. Jeng, Macromol. Rapid Commun. 2001, 22, 601-606; b) W.-J. Kuo, G.-H. Hsiue, R.-J. Jeng, J. Mater. Chem. 2002, 12, 868-878; c) H.-C. Tsai,
W.-J. Kuo, G.-H. Hsiue, Macromol. Rapid Commun. 2005 , 26, 986-991.

[54] J.-F. Xing, W.-Q. Chen, J. Gu, X.-Z. Dong, N. Takeyasu, T. Tanaka, X.-M. Duan, S. Kawata, J. Mater. Chem. 2007, 17, 1433-1438.

[55] a) S. Ramkumar, S. Manoharan, S. Anandan, Dyes Pigm. 2012, 94, 503-511; b) J. He, J. Hua, G. Hu, X. J. Yin, H. Gong, C. Li., Dyes Pigm. 2014, 104, 75-82.

[56] Y. Wei, X. Zhang, L. Wang, Y. Liu, T. Bing, X. Liu, D. Shangguan, RSC Adv. 2015, 5, 75911-75917.

[57] G. S. Kumar, K. Srinivas, B. Shanigaram, D. Bharath, S. P. Singh, K. Bhanuprakash, V. J. Rao, A. Islam, RSC Adv. 2014, 4, 13172-13181.

[58] a) M. Lehmann, C. Köhn, H. Kresse, Z. Vakhovskaya, Chem. Commun. 2008, 1768-1770; b) M. Lehmann, J. Seltmann, A. A. Auer, E. Prochnow, U. Benedikt, J. Mater. Chem. 2009, 19, 1978-1988; c) J. Seltmann, A. Marini, B. Mennucci, S. Dey, S. Kumar, M. Lehmann, Chem. Mater. 2011, 23, 2630 2636.

[59] X. Mei, G. Wen, J. Wang, H. Yao, Y. Zhao, Z. Lin, Q. Ling, J. Mater. Chem. C 2015, 3, 7267-7271.

[60] a) N. N. P. Moonen, C. Boudon, J.-P. Gisselbrecht, P. Seiler, M. Gross, F. Diederich, Angew. Chem. Int. Ed. 2002, 41, 3044-3047; b) N. N. P. Moonen, R. Gist, C. Boudon, J.-P. Gisselbrecht, P. Seiler, T. Kawai, A. Kishioka, M. Gross, M. Irie, F. Diederich, Org. Biomol. Chem. 2003, 1, 2032-2034; c) N. N. P. Moonen, W. C. Pomerantz, R. Gist, C. Boudon, J.-P. Gisselbrecht, T. Kawai, A. Kishioka, M. Gross, M. Irie, F. Diederich, Chem. Eur. J. 2005, 11, 3325-3341; d) F. Bureš, W. B. Schweizer, J. C. May, C. Boudon, J.-P. Gisselbrecht, M. Gross, I. Biaggio, F. Diederich, Chem. Eur. J. 2007, 13, 5378-5387.

[61] a) G. Jiang, T. Michinobu, W. Yuan, M. Feng, Y. Wen, S. Du, H. Gao, L. Jiang, Y. Song, F. Diederich, D. Zhu, Adv. Mater. 2005, 17, 2170-2173; b) J. C. May, I. Biaggio, F. Bureš, F. Diederich, Appl. Phys. Lett. 2007, 90, 251106; d) F. Bureš, O. Pytela, M. Kivala, F. Diederich, J. Phys. Org. Chem. 2011, 24, 274-281; e) M. G. Kuzyk, J. Mater. Chem. 2009, 19, $7444-$ 7465.

[62] a) H. S. Nalwa, K. Nakajima, T. Watanabe, K. Nakamura, A. Yamada, S. Miyata, Jpn. J. Appl. Phys. 1991, 30, 983-989; b) H. S. Nalwa, T. Watanabe, S. Miyata, Adv. Mater. 1995, 7, 754-758; c) H. S. Nalwa, T. Watanabe, K. Ogino, H. Sato, S. Miyata, J. Mater. Sci. 1998, 33, 3699-3710.

[63] a) T. Kinnibrugh, S. Bhattacharjee, P. Sullivan, C. Isborn, B. H. Robinson, B. E. Eichinger, J. Phys. Chem. B 2006, 110, 13512-13522; b) H.-P. Li, K. Han, G. Tang, X.-P. Shen, H.-T. Wang, Z.-M. Huang, Z.-H. Zhang, L. Bai, Z.-Y. Wang, Chem. Phys. Lett. 2007, 444, 80-84; c) H.-P. Li, K. Han, C.-Y. Wang, X.-P. Shen, H.-T. Wang, G. Tang, J. Mol. Struct. THEOCHEM 2008, 870, 49-52; d) P.-W. Liu, K. Zhao, G.-C. Han, Chem. Phys. Lett. 2011, 514, 226-233.

[64] a) H. Kang, P. Zhu, Y. Yang, A. Facchetti, T. J. Marks, J. Am. Chem. Soc. 2004, 126, 15974-15975; b) H. Kang, G. Evmenenko, P. Dutta, K. Clays, K. Song, T. J. Marks, J. Am. Chem. Soc. 2006, 128, 6194-6205. 
[65] a) A. J. Zucchero, P. L. McGrier, U. H. F. Bunz, Acc. Chem. Res. 2010, 43, 397-408; b) J. Tolosa, K. M. Solntsev, L. M. Tolbert, U. H. F. Bunz, J. Org. Chem. 2010, 75, 523-534; c) E. A. Davey, A. J. Zucchero, O. Trapp, U. H. F. Bunz, J. Am. Chem. Soc. 2011, 133, 7716-7718; d) M. N. Gard, A. J. Zucchero, G. Kuzmanich, C. Oelsner, D. Guldi, A. Dreuw, U. H. F. Bunz, M. A. Garcia-Garibay, Org. Lett. 2012, 14, 1000-1003; e) P. L. McGrier, K. M. Solntsev, S. Miao, L. M. Tolbert, O. R. Miranda, V. M. Rotello, U. H. F. Bunz, Chem. Eur. J. 2008, 14, 4503-4510; f) M. Hauck, J. Schönhaber, A. J. Zucchero, K. I. Hardcastle, T. J. J. Müller, U. H. F. Bunz, J. Org. Chem. 2007, 72, 6417-6725; g) A. J. Zucchero, J. N. Wilson, U. H. F. Bunz, J. Am. Chem. Soc. 2006, 128, 1187211881; h) J. N. Wilson, K. I. Hardcastle, M. Josowicz, U. H. F. Bunz, Tetrahedron 2004, 60, 7157-7167.

[66] a) J. A. Marsden, J. J. Miller, L. D. Shirtcliff, M. M. Haley, J. Am. Chem. Soc. 2005, 127, 2464-2476; b) A. D. Slepkov, F. A. Hegmann, R. R. Tykwinski, K. Kamada, K. Ohta, J. A. Marsden, E. L. Spitler, J. J. Miller, M. M. Haley, Opt. Lett. 2006, 31, 3315-3317; c) E. L. Spitler, L. D. Shirtcliff, M. M. Haley, J. Org. Chem. 2007, 72, 86-96; d) S. Samori, S. Tojo, M. Fujitsuka, E. I. Spitler, M. M. Haley, T. Majima, J. Org. Chem. 2007, 72, 2785-2793; e) D. T. Chase, B. S. Young, M. M. Haley, J. Org. Chem. 2011, 76, 4043-4051.

[67] L. Dokládalová, F. Bureš, W. Kuznik, I. V. Kityk, A. Wojciechowski, T. Mikysek, N. Almonasy, M. Ramaiyan, Z. Padělková, J. Kulhánek, M. Ludwig, Org. Biomol. Chem. 2014, 12, 5517-5527.

[68] F. Bureš, H. Čermáková, J. Kulhánek, M. Ludwig, W. Kuznik, I. V. Kityk, T. Mikysek, A. Růžička, Eur. J. Org. Chem. 2012, 529-538.

[69] a) N. Almonasy, F. Bureš, M. Nepraš, H. Přichystalová, G. Grampp, Dyes Pigm. 2014, 108, 50-56; b) J. Kulhánek, F. Bureš, M. Ludwig, Beilstein J. Org. Chem. 2009, 5, No. 11.

[70] Y. Zhao, C. Zhang, K. F. Chin, O. Pytela, G. Wei, H. Liu, F. Bureš, Z. Jiang, RSC Adv. 2014, 4, 30062-30067.

[71] X. Liu, X. Ye, F. Bureš, H. Liu, Z. Jiang, Angew. Chem. Int. Ed. 2015, 54, 11443-11447.

[72] a) Q. Anjun, K. Hu, L. Shaojun, Y. Cheng, Synth. Met. 2003, 137, 1517-1518; b) A. Qin, Z. Yang, F. Bai, C. Ye, J. Polym. Sci. A1 2003, 41, 2846-2853; c) A. Qin, F. Bai, C. Ye, J. Mol. Struct. THEOCHEM 2003, 631, 79-85.

[73] a) H. Kang, S. Li, P. Wang, W. Wu, C. Ye, Synth. Met. 2001, 121, 1469-1470; b) Z. Yang, S. Li, C. Ye, Synth. Met. 2003, 137, 1519-1520; c) S. Li, Z. Yang, C. Ye, Chin. J. Polym. Sci. 2004, 22, 453-457; d) P. Wang, P. Zhu, W. Wu, H. Kang, C. Ye, Phys. Chem. Chem. Phys. 1999, 1, 3519-3525.

[74] a) A. Janiga, D. Bednarska, B. Thorsted, J. Brewer, D. T. Gryko, Org. Biomol. Chem. 2014, 12, 2874-2881; b) R. Orłowski, M. Banasiewicz, G. Clermont, F. Castet, R. Nazir, M. Blanchard-Desce, D. T. Gryko, Phys. Chem. Chem. Phys. 2015, 17, 23724-23731.

[75] a) X. Sun, Y. Liu, S. Chen, W. Qiu, G. Yu, Y. Ma, T. Qi, H. Zhang, X. Xu, D. Zhu, Adv. Funct. Mater. 2006, 16, 917925; b) X. Sun, Y. Zhou, W. Wu, Y. Liu, W. Tian, G. Yu, W. Qiu, S. Chen, D. Zhu J. Phys. Chem. B 2006, 110, 7702-
7707; c) H. Shang, H. Fan, Y. Liu, W. Hu, Y. Li, X. Zhan, J. Mater. Chem. 2011, 21, 9667-9673; d) S. Bibi, P. Li, J. Zhang, J. Mater. Chem. A 2013, 1, 13828-13841.

[76] a) J. E. Klarke, G. S. Tulevski, K. Sugo, A. de Picciotto, K. A. White, C. Nuckolls, J. Am. Chem. Soc. 2003, 125, 60306031 ; b) J. E. Klarke, G. S. Tulevski, C. Nuckolls, Langmuir 2004, 20, 10068-10072; c) G. M. Florio, J. E. Klarke, M. O. Pasamba, T. L. Werblowsky, M. Hyers, B. J. Berne, M. S. Hybertsen, C. Nuckolls, G. W. Flynn, Langmuir 2006, 22, 10003-10008.

[77] a) J. Lim, T. A. Albright, B. R. Martin, O. S. Miljanić, J. Org. Chem. 2011, 76, 10207-10219; b) M. A. Saeed, H. T. M. Le, O. Š. Miljanić, Acc. Chem. Res. 2014, 47, 2074-2083; c) H. T. M. Le, N. S. El-Hamdi, O. Š. Miljanić, J. Org. Chem. 2015, 80, 5210-5217.

[78] a) X. Wang, J. Yan, Y. Zhou, J. Pei, J. Am. Chem. Soc. 2010, 132, 15872-15874; b) Q. Zhang, R. Tang, X. Sun, Y. Fu, X. Wang, F. Qiu, W. Zhao, S. Han, W. Wang, X. Zhuang, F. Zhang, Tetrahedron Lett. 2015, 56, 4011-4015.

[79] a) K. H. Jung, S. Y. Bae, K. H. Kim, M. J. Cho, K. Lee, Z. H. Kim, D. H. Choi, D. H. Lee, D. S. Chung, C. E. Park, Chem. Commun. 2009, 5290-5292; b) H. C. Zhang, E. Q. Guo, Y. L. Zhang, P. H. Ren, W. J. Yang, Chem. Mater. 2009, 21, 5125-5135; c) D. Zhang, Y. Gao, J. Dong, Q. Sun, W. Liu, S. Xue, W. Yang, Dyes Pigm. 2015, 113, 307-311.

[80] a) H. Zhang, Y. Wang, K. Shao, Y. Liu, S. Chen, W. Qiu, X. Sun, T. Qi, Y. Ma, G. Yu, Z. Su, D. Zhu, Chem. Commun. 2006, 755-757; b) J. You, G. Lia, R. Wang, Q. Nie, Z. Wang, J. Li, Phys. Chem. Chem. Phys. 2011, 13, 1782517830 ; c) Z. Jin, D. Wang, X. Wang, P. Liang, Y. Mi, H. Yang, Tetrahedron Lett. 2013, 54, 4859-4864; d) K. R. Idzik, P. Ledwon, T. Licha, W. Kuznik, M. Lapkowski, J. Frydel, Dyes Pigm. 2014, 103, 55-61.

[81] a) C.-H. Lee, K. N. Plunkett, Org. Lett. 2013, 15, 1202 1205; b) J.-B. Giguère, J. Boismenu-Lavoie, J.-F. Morin, J. Org. Chem. 2014, 79, 2404-2418.

[82] a) F. Bureš, W. B. Schweizer, C. Boudon, J.-P. Gisselbrecht, M. Gross, F. Diederich, Eur. J. Org. Chem. 2008, 994-1004; b) Y.-L. Wu, F. Bureš, P. D. Jarowski, W. B. Schweizer, C. Boudon, J.-P. Gisselbrecht, F. Diederich, Chem. Eur. J. 2010, 16, 9592-9605.

[83] Y.-L. Wu, F. Tancini, W. B. Schweizer, D. Paunescu, C. Boudon, J.-P. Gisselbrecht, P. D. Jarowski, E. Dalcanale, F. Diederich, Chem. Asian J. 2012, 7, 1185-1190.

[84] A. Patel, F. Bureš, M. Ludwig, J. Kulhánek, O. Pytela, A. Růžička, Heterocycles 2009, 78, 999-1013.

[85] a) J. Kulhánek, F. Bureš, O. Pytela, T. Mikysek, J. Ludvík, A. Růžička, Dyes Pigm. 2010, 85, 57-65; b) F. Bureš, J. Kulhánek, T. Mikysek, J. Ludvík, J. Lokaj, Tetrahedron Lett. 2010, 51, 2055-2058; c) J. Lokaj, J. Moncol, F. Burě̌, J. Kulhánek, J. Chem. Crystallogr. 2011, 41, 834-837; d) J. Kulhánek, F. Bureš, W. Kuznik, I. V. Kityk, T. Mikysek, A. Růžička, Chem. Asian J. 2013, 8, 465-475.

[86] J. Kulhánek, F. Bureš, T. Mikysek, J. Ludvík, O. Pytela, Dyes Pigm. 2011, 90, 48-55. 
[87] J. Kulhánek, F. Bureš, O. Pytela, T. Mikysek, J. Ludvík, Chem. Asian J. 2011, 6, 1604-1612.

[88] a) J. Kulhánek, F. Bureš, A. Wojciechowski, M. MakowskaJanusik, E. Gondek, I. V. Kityk, J. Phys. Chem. A 2010, 114, 9440-9446; b) M. Nepraš, N. Almonasy, F. Bureš, J. Kulhánek, M. Dvořák, M. Michl, Dyes Pigm. 2011, 91, 466473; c) M. Makowska-Janusik, I. V. Kityk, J. Kulhánek, F. Bureš, J. Phys. Chem. A 2011, 115, 12251-12258; d) M. Danko, P. Hrdlovič, J. Kulhánek, F. Bureš, J. Fluoresc. 2011, 21, 1779-1787; e) M. Danko, F. Bureš, J. Kulhánek, P. Hrdlovič, J. Fluoresc. 2012, 22, 1165-1176.

[89] A. Plaquet, B. Champagne, J. Kulhánek, F. Bureš, E. Bogdan, F. Castet, L. Ducasse, V. Rodriguez, ChemPhysChem 2011, $12,3245-3252$.

[90] N. Almonasy, F. Bureš, J. Kulhánek, O. Machalický, J. Mater. Sci. Eng. A 2011, 1, 146-151.

[91] M. Pokladko-Kowar, N. Nosidlak, E. Gondek, I. V. Kityk, F. Bureš, J. Kulhánek, P. Karasiński, Opt. Quantum Electron. 2016, 48, 82.

[92] C. R. Moylan, R. D. Miller, R. J. Twieg, K. M. Betterton, V. Y. Lee, T. J. Matray, C. Nguyen, Chem. Mater. 1993, 5, 1499-1508.

[93] a) J. Santos, E. A. Mintz, O. Zehnder, C. Bosshard, X. R. Bu, P. Günter, Tetrahedron Lett. 2001, 42, 805-808; b) S. Wang, L. Zhao, Z. Xu, C. Wu, S. Cheng, Mater. Lett. 2002, 56, 1035-1038; c) W. Wang, C. Ye, D. Wang, ARKIVOC 2003, ii, 59-69; d) G. Ozturk, D. Karakas, F. Karadag, G. Ozturk, C. Yorgun, J. Fluoresc. 2012, 22, 1159-1164; e) J. Pina, J. S. Seixa de Melo, R. M. F. Batista, S. P. G. Costa, M. M. M. Raposo, J. Phys. Chem. B 2010, 114, 4964-4972; f) E. Oliveira, R. M. F. Baptista, S. P. G. Costa, M. M. M. Raposo, C. Lodeiro, Inorg. Chem. 2010, 49, 10847-10857; g) R. M. F. Batista, S. P. G. Costa, M. Belsley, M. M. M. Raposo, Dyes Pigm. 2009, 80, 329-336; h) R. M. F. Batista, S. P. G. Costa, M. Belsley, C. Lodeiro, M. M. M. Raposo, Tetrahedron 2008, 64, 9230-9238.

[94] a) K. Feng, L. De Boni, L. Misoguti, C. R. Mendonça, M. Meador, F.-L. Hsu, X. R. Bu, Chem. Commun. 2004, 11781180; b) K. Feng, F.-L. Hsu, D. Van DerVeer, K. Bota, X. R. Bu, J. Photochem. Photobiol. A 2004, 165, 223-228; c) L. De Boni, D. L. Silva, U. M. Neves, K. Feng, M. Meador, X. R. $\mathrm{Bu}, \mathrm{L}$. Misoguti, C. R. Mendonça, Chem. Phys. Lett. 2005, 402, 474-478; d) J. Ren, S.-M. Wang, L.-F. Wu, Z.-X. Xu, B.-H. Dong, Dyes Pigm. 2008, 76, 310-314.

[95] a) A. Fülöpová, P. Magdolen, M. Károlyiová, I. Sigmundová, P. Zahradník, J. Heterocycl. Chem. 2013, 50, 563-567; b) E. Aqad, M. V. Lakshmikantham, M. P. Cava, R. M. Metzger, J. Org. Chem. 2005, 70, 768-775.

[96] a) T. Manifar, S. Rohani, Can. J. Chem. Eng. 2004, 84, 323334; b) Y. N. Luponosov, A. N. Solodukhin, S. A. Ponomarenko, Polym. Sci. 2014, 56, 104-134; c) Z. Ning, H. Tian, Chem. Commun. 2009, 5483-5495; d) A. Mahmood, Sol. Energy 2016, 123, 127-144; e) J. Pina, J. S. Seixas de Melo, R. M. F. Batista, S. P. G. Costa, M. M. M. Raposo, J. Org. Chem. 2013, 78, 11389-11395.
[97] D. Cvejn, E. Michail, I. Polyzos, N. Almonasy, O. Pytela, M. Klikar, T. Mikysek, V. Giannetas, M. Fakis, F. Bureš, J. Mater. Chem. C 2015, 3, 7345-7355.

[98] D. Cvejn, E. Michail, K. Seintis, M. Klikar, O. Pytela, T. Mikysek, N. Almonasy, M. Ludwig, V. Giannetas, M. Fakis, F. Bureš, RSC Adv. 2016, 6, 12819-12828.

[99] D. Cvejn, S. Achelle, O. Pytela, J.-P. Malval, A. Spangenberg, A. Cabon, F. Bureš, F. Robin-le Guen, Dyes Pigm. 2016, 124, 101-109.

[100] K. Melánová, D. Cvejn, F. Bureš, V. Zima, J. Svoboda, L. Beneš, T. Mikysek, O. Pytela, P. Knotek, Dalton Trans. 2014, 43, 10462-10470.

[101] a) M.-H. Ha-Thi, V. Souchon, A. Hamdi, R. Métivier, V. Alain, K. Nakatani, P. G. Lacroix, J.-P. Genêt, V. Michelet, I. Leray, Chem. Eur. J. 2006, 12, 9056-9065; b) S. Yamaguchi, T. Shirasaka, K. Tamao, Org. Lett. 2000, 2, 4129-4132; c) Y. Liu, X. Xu, F. Zheng, Y. Cui, Angew. Chem. Int. Ed. 2008, 47, 4538-4541; d) J. Yoshino, Y. Nakamura, S. Kunitomo, N. Hayashi, H. Higuchi, Tetrahedron Lett. 2013, 54, 2817 2820.

[102] a) L. Porrès, C. Katan, O. Mongin, T. Pons, J. Mertz, M. Blanchard-Desce, J. Mol. Struct. 2004, 704, 17-24; b) M. M. Oliva, J. Casado, J. T. L. Navarrete, G. Hennrich, S. van Cleuvenbergen, I. Asselberghs, K. Clays, M. C. R. Delgado, J.-L. Brédas, J. S. S. de Melo, L. De Cola, Chem. Eur. J. 2009, 15, 8223-8234; c) H.-F. Huang, S.-H. Xu, Y.-B. He, C.-C. Zhu, H.-L. Fan, X.-H. Zhou, X.-C. Gao, Y.-F. Dai, Dyes Pigm. 2013, 96, 705-713; d) S. Pelz, J. Zhang, I. Kanelidis, D. Klink, L. Hyzak, V. Wulf, O. J. Schmitz, J.-C. Gasse, R. Frahm, A. Pütz, A. Colsmann, U. Lemmer, E. Holder, Eur. J. Org. Chem. 2013, 4761-4769; e) F.-A. Martin, C. Baudequin, C. Fiol-Petit, M. Darabantu, Y. Ramondenc, N. Plé, Tetrahedron 2014, 70, 2546-2555; f) T. Shimasaki, Y. Takiyama, Y. Nishihara, A. Morimoto, N. Teramoto, M. Shibata, Tetrahedron Lett. 2015, 56, 260-263; g) S. Varghese, N. S. S. Kumar, A. Krishna, D. S. S. Rao, S. K. Prasad, S. Das, Adv. Funct. Mater. 2009, 19, 2064-2073; h) C. C. Paraschivescu, N. D. Hădade, A. G. Coman, A. Gautier, F. Cisnetti, M. Matache, Tetrahedron Lett. 2015, 56, 39613964; i) M.-S. Yuan, Q. Wang, W.-J. Wang, T.-B. Li, L. Wang, W. Deng, Z.-T. Du, J.-R. Wang, Dyes Pigm. 2012, 95, 236-243.

[103] C. K. R. Namboodiri, P. B. Bisht, R. Mukkamala, B. Chandra, I. S. Aidhen, Chem. Phys. 2013, 415, 190-195.

[104] S. Achelle, Y. Ramondenc, G. Dupas, N. Plé, Tetrahedron 2008, 64, 2783-2791.

[105] a) Y. Z. Cui, Q. Fang a, H. Lei, G. Xue, W. T. Yu, Chem. Phys. Lett. 2003, 377, 507-511; b) L. Liu, Z. Q. Zhou, J. P. Shi, C. G. Lu, Y. P. Cui, G. Y. Lu, Chin. Chem. Lett. 2011 , 22, 1147-1150; c) L. Wei, J. P. Shi, Z. Q. Zhou, Y. P. Cui, H. W. Hu, G. Y. Lu, Chin. Chem. Lett. 2012, 23, 867-870; d) L. Zou, Z. Liu, X. Yan, Y. Liu, Y. Fu, J. Liu, Z. Huang, X. Chen, J. Qin, Eur. J. Org. Chem. 2009, 5587-5593; e) T. Yasuda, T. Shimizu, F. Liu, G. Ungar, T. Kato, J. Am. Chem. Soc. 2011 , 133, 13437-13444; f) G. Argouarch, R. Veillard, T. Roisnel, A. Amar, H. Meghezzi, A. Boucekkine, V. Hugues, O. 
Mongin, M. Blanchard-Desce, F. Paul, Chem. Eur. J. 2012, 18, 11811-11827; g) J. Liu, K. Wang, F. Xu, Z. Tang, W. Zheng, J. Zhang, C. Li, T. Yu, X. You, Tetrahedron Lett. 2011, 52, 6492-6496; h) V. S Padalkar, V. S Patil, N. Sekar, Chem. Cent. J. 2011, 5, 77; i) Y. Jiang, Y. Wang, B. Wang, J. Yang, N. He, S. Qian, J. Hua, Chem. Asian J. 2011, 6, 157-
165; j) Y. Jiang, Y. Wang, J. Hua, J. Tang, B. Li, S. Qian, H. Tian, Chem. Commun. 2010, 46, 4689-4691. 